\title{
Artykuey
}

KLIO. Czasopismo poświęcone dziejom Polski i powszechnym

PL ISSN 1643-8191, t. 21 (2) 2012, s. 107-142

\section{Marek Białokur}

(Opole)

\section{Goracy polityczny grudzień 1922 roku we wspótczesnej edukacji historycznej}

Casus szkolnych podręczników do nauczania historii

W

2012 roku obchodzimy dziewięćdziesiątą rocznicę burzliwych wydarzeń grudnia 1922 roku. Szczególnym wstrząsem dla polskiego społeczeństwa było zamordowanie 16 grudnia tegoż roku pierwszego prezydenta Rzeczypospolitej Gabriela Narutowicza przez Eligiusza Niewiadomskiego ${ }^{1}$. Wydarzenie to oraz poprzedzająca je ostra polityczna walka, której areną była nie tylko sala sejmowa i łamy popularnych tytułów prasowych, ale i ulice stolicy Polski, w istotny sposób zaważyło na historii

1 Prof. dr hab. Marek Andrzejewski z Instytutu Historii Uniwersytetu Gdańskiego (UG) słusznie zauważył, że zainteresowanie postacią Gabriela Narutowicza zarówno w okresie międzywojennym, PRL-u, jak i po 1989 roku, tj. w III Rzeczypospolitej koncentruje się na ostatnim tygodniu jego życia (9-16 grudnia 1922 roku). Tę ze wszech miar krzywdzącą dla postaci tak wielowymiarowej jak G. Narutowicz sytuację zapewne trudno będzie zmienić, co dowodzi, jak silne piętno na historii odciska jej polityczny wymiar. Tym cenniejsze są więc publikacje wspomnianego wykładowcy UG, który od wielu lat konsekwentnie przybliża polskim i zagranicznym czytelnikom biografię G. Narutowicza w pełnym wymiarze, ale jednocześnie bez nadmiernego wyolbrzymiana jego zasług. Zob.: M. Andrzejewski, Kilka uwag o Gabrielu Narutowiczu, [w:] Polska i Polacy. Studia z dziejów polskiej myśli i kultury politycznej XIX i XX wieku, red. M. Mroczko, Gdańsk 2011, s. 43; idem, Gabriel Narutowicz i jego rezygnacja z profesury w zurychskiej politechnice w 1919 r., „Dzieje Najnowsze” 2005, R. XXXVII, nr 3, s. 137-139. 
międzywojennej Polski². Wydarzenie tej rangi, w naturalny sposób, zajmuje ważne miejsce w szkolnej edukacji historycznej. Konstatacja ta odnosi się zarówno do narracji historycznej prezentowanej w polskich szkołach przed rokiem 1939, w kraju rządzonym przez obóz komunistyczny tj. pomiędzy 1945 a 1989 rokiem oraz w wolnej Polsce, którą otwierają wydarzenia tzw. Jesieni Ludów/Narodów. Celem artykułu, wpisującego się w rocznicową debatę, jest przedstawienie syntetycznej analizy wydarzeń z grudnia 1922 roku widzianej przez pryzmat jednego ze źródeł uczniowskiej wiedzy historycznej, jakimi są szkolne podręczniki ${ }^{3}$. Zdaniem wielu dydaktyków historii zajmują one wyjątkową pozycję w gronie źródeł uczniowskiej wiedzy o przeszłości ${ }^{4}$ W podsumowaniu artykułu znalazło się również miejsce dla wydanych w ostatnich kilku latach i mających znaczenie dla tematu artykułu publikacji popularnych i popularnonaukowych. Dziewięćdziesiąta rocznica wydarzeń grudniowych 1922 r., a przede wszystkim zabójstwo prezydenta G. Narutowicza oraz pojawiające się w jej trakcie wypowiedzi nie pozostają bez wpływu na proces nauczania historii w polskich szkołach. Nie bez znaczenia jest fakt, że od września 2012 roku uczniowie klas pierwszych szkół ponadgimnazjalnych realizują nową podstawę programową nauczania historii. Zgodnie z jej

${ }^{2} \mathrm{~W}$ polskiej historiografii, publicystyce historycznej oraz licznych artykułach popularnych i popularnonaukowych od wielu lat toczą się spory na temat roli, jaką w dziejach międzywojennej Polski odegrały burzliwe wydarzenia grudnia 1922 r. Lista publikacji, które w tym miejscu należałoby wymienić, pragnąc pokazać różnice w ocenach ówczesnych wydarzeń, jest bardzo długa. Część z nich wymieniona została w ostatniej części artykułu. Zdecydowanie największe emocje, na przestrzeni minionych dziewięciu dekad, wzbudzała śmierć prezydenta G. Narutowicza. Znacznie skromniej prezentuje się lista publikacji poświęconych innym aspektom grudniowych wydarzeń, które zostały przysłonięte lub też zdeterminowane przez „strzały w Zachęcie.

3 Umowną cezurę czasową stanowi rok 1989, po którym w Polsce nastąpił gwałtowny rozwój rynku wydawniczego. Dotyczy to również podręczników szkolnych, na których wydawanie monopol utraciły wydawnictwa kontrolowane przez państwo.

${ }^{4}$ Pozycja klasycznego papierowego podręcznika, przez długie lata uznawanego, obok nauczyciela, za podstawowe źródło wiedzy historycznej uczniów na różnych poziomach nauczania, na przestrzeni ostatnich kilku lat, zaczęła wyraźnie słabnąć w konfrontacji z ogólnodostępnymi materiałami historycznymi dostępnymi w encyklopediach internetowych oraz na specjalistycznych stronach historycznych dostępnych w ogólnoświatowej sieci komputerowej. Taki stan rzeczy potwierdzają m.in. wyniki badań przeprowadzonych w ostatnim kwartale 2011 roku przez $\mathrm{dr}$ Annę Gołębiowską z Instytutu Historii Uniwersytetu Opolskiego. Badania dotyczy świadomości historycznej oraz źródeł wiedzy historycznej uczniów i studentów w województwie opolskim na temat stanu wojennego (M. Białokur, M. Fic, A. Gołębiowska, Przerwana droga do niepodległości. Stan wojenny 13 XII 1981-22 VII 1983. Świadomość - Edukacja - Kultura, Opole-Toruń 2012, s. 29-30). 
założeniami wszyscy uczniowie wspomnianych szkół mają obowiązek rozpoczynać naukę historii od wydarzeń kończących 1918 rok, czyli zakończenie I wojny światowej. Oznacza to, że jednym z pierwszych zagadnień omawianych na lekcjach, w kontekście historii ojczystej, stanowić będzie proces kształtowania się podstaw ustrojowych II Rzeczypospolitej i związane z nim życie polityczne odrodzonego krajus .

Gorący polityczny grudzień 1922 roku poprzedziło narastanie napięcia na linii Naczelnik Państwa Józef Piłsudski wraz z grupą zwolenników i sympatyków, a prawicą skupioną wokół obozu narodowego (Narodowej Demokracji $)^{6}$. W połowie 1922 roku rywalizacja obu grup toczyła się głównie na forum Sejmu Ustawodawczego, z którym Naczelnik Państwa otwarcie rywalizował o wpływy, lansując na urząd premiera swoich kandydatów,

5 Potwierdzenie roli i znaczenia wydarzeń grudniowych 1922 roku w podręcznikach wydanych na potrzeby nowej podstawy programowej kształcenia ogólnego przynosi analiza pierwszych opracowań udostępnionych nauczycielom, w wersji demonstracyjnej, testowej, promocyjnej lub tzw. edycji specjalnej nieprzeznaczonej do sprzedaży, tj. przed uzyskaniem pozytywnych opinii rzeczoznawców Ministerstwa Edukacji Narodowej. Zob.: S. Roszak, J. Kłaczkow, Poznać przeszłość. Wiek XX. Podręcznik do historii dla szkót ponadgimnazjalnych. Zakres podstawowy. Klasa 1, Nowa Era, Warszawa 2011, s. 91; R. Dolecki, K. Gutowski, J. Smoleński, Po prostu historia. Zakres podstawowy. Podręcznik do liceum i technikum, Wydawnictwa Szkolne i Pedagogiczne, Warszawa 2012, s. 49-50; A. Brzozowski, G. Szczepański, Ku wspótczesności. Dzieje najnowsze 1918-2006. Podręcznik do historii dla klasy I liceum i technikum - zakres podstawowy, Wydawnictwo Piotra Marciszuka STENTOR, Warszawa 2012, s. 38-41; J. Ustrzycki, Historia. Zakres podstawowy. Podręcznik dla szkót ponadgimnazjalnych, Wydawnictwo Pedagogiczne OPERON, Gdynia 2012, s. 52; B. Burda, B. Halczak, R. M. Józefiak. A. Roszak, M. Szymczak, Historia najnowsza. Podręcznik dla szkót ponadgimnazjalnych. Zakres podstawowy, Wydawnictwo Pedagogiczne OPERON, Gdynia 2012, s. 76-77. W zestawieniu nie zostały wymienione podręczniki udostępnione nauczycielom historii po 31 marca 2012 roku.

6 „Gdy dziś z odległości kilku dziesiątków lat patrzę na dwudziestolecie Polski niepodległej (1920-1939) - pisał w pamiętniku jeden z czołowych publicystów endeckich Stanisław Kozicki - to widzę z coraz większą dokładnością, że osią, koło której obracała się polityka polska tego okresu, była walka Demokracji Narodowej z Piłsudskim, jego otoczeniem i jego następcami”, S. Kozicki, Pamiętnik 1876-1939, opracowanie, przedmowa i przypisy M. Mroczko, Słupsk 2009, s. 490. Wspomnień i relacji analogicznie oceniających ówczesną sytuację można wymienić długą listę. Opisaną sytuację bardzo plastycznie ilustruje również międzywojenna prasa reprezentująca różne opcje polityczne. Zob. także: T. Nałęcz, Rządy Sejmu 1921-1926, Warszawa 1991, s. 18-21; M. Białokur, Józef Pitsudski i sanacja w oczach opozycji parlamentarnej (1922-1935). Szkic z dziejów polskiego parlamentaryzmu, [w:] Józef Pitsudski a parlamentaryzm polski, red. A. Adamczyk, Warszawa-Bełchatów 2009, s. 117, 123, 126-127; E. Maj, Komunikowanie polityczne Narodowej Demokracji 1918-1939, Lublin 2010, s. 494 i n. 
przy jednoczesnym odrzucaniu kandydatur zgłaszanych przez prawicę ${ }^{7}$. Echa tych ważnych wydarzeń w narracjach podręcznikowych najczęściej wiązane są z konsekwencjami wprowadzenia w Polsce systemu demokracji parlamentarnej, w którym władza ustawodawcza wyraźnie dominowała nad stosunkowo słabą władzą wykonawczą .

Demokracja i parlamentaryzm - jak podkreślił jeden z autorów podręczników - w dziewiętnastowiecznej Europie to procesy narastające stopniowo, głównie dzięki ustępstwom ze strony tradycyjnych elit i monarchii. Jednak w wielu powstających po 1918 roku państwach zamiast ewolucji stosunków politycznych nastąpiła ich gwałtowna przemiana. Także w II Rzeczypospolitej wygrał egalitaryzm (idea równych praw dla wszystkich) oraz wiara, że masy nadrobią braki w świadomości obywatelskiej na drodze demokratycznego doświadczenia?

Przy tej okazji, także inni autorzy zwrócili uwagę, że napięcie na linii J. Piłsudski - obóz narodowy spotęgowało się wraz ze zbliżaniem wyborów do Sejmu i Senatu I kadencji, i było szczególnie widoczne przy uchwalaniu ordynacji wyborczej w lipcu 1922 roku $^{10}$. Na kartach pojedynczych opraco-

7 W wyniku działań podjętych przez Józefa Piłsudskiego zaufanie większości posłów stracił rząd Antoniego Ponikowskiego. Z kolei polityczni adwersarze Naczelnika doprowadzili do dymisji gabinet Artura Śliwińskiego, którego desygnował na urząd premiera. O znaczeniu tych wydarzeń i konieczności prowadzenia badań nad dziejami wewnętrznymi II Rzeczypospolitej ze szczególnym uwzględnieniem 1922 roku konsekwentnie od wielu lat postuluje Janusz Faryś (idem, Konflikt Naczelnika Państwa z Sejmem Ustawodawczym w 1922 roku, „Dzieje Najnowsze” 1975, R. VII, nr 3, s. 39-51; idem, Stanistaw Stroński wobec sytuacji wewnętrznej Polski w 1922 roku, [w:] Polska leży na Zachodzie. Studia z dziejów Polski i Europy dedykowane Pani Profesor Teresie Kulak, red. W. Wrzesiński, M. Masnyk, K. Kawalec, Toruń 2011, s. 301). Szerzej na temat okoliczności powstania i działalności wspomnianych gabinetów zob.: Od Moraczewskiego do Składkowskiego. Gabinety Polski Odrodzonej 1918-1939, red. J. Faryś, A. Wątor i H. Walczak, Szczecin 2010, s. 101-116; Prezydenci i premierzy Drugiej Rzeczypospolitej, red. A. Chojnowski i P. Wróbel, Wrocław 1992, s. 153-176.

${ }^{8}$ J. Kochanowski, P. Matusik, Człowiek i historia. Część 4. Czasy nowożytne i najnowsze (XIX i XX wiek). Kształcenie w zakresie rozszerzonym. Podręcznik dla liceum ogólnoksztatcącego, liceum profilowanego i technikum, Wydawnictwa Szkolne i Pedagogiczne, Warszawa 2004, s. 47.

9 J. Wróbel, Odnaleźć przesztość 2. Historia od 1815 roku do wspótczesności. Ksztatcenie $w$ zakresie podstawowym. Liceum ogólnokształcace, Liceum profilowane, Technikum, Wydanie pierwsze, Wydawnictwa Szkolne i Pedagogiczne, Warszawa 2003, s. 198.

10 S. Sierpowski, Historia najnowsza (1918-1997). Podręcznik dla szkoty średniej, Wydanie drugie, Polska Oficyna Wydawnicza „BGW”, Warszawa 1997, s. 46. 
wań odnotowano, że przyczyną rywalizacji była sprawa kredytów dla armii, o które występował Naczelnik Państwa, a blokował zdominowany przez niechętne mu ugrupowania Sejm Ustawodawczy ${ }^{11}$. W tej otwartej rywalizacji politycznej żadna ze stron nie potrafiła skutecznie zdominować politycznego adwersarza. Prawicy nie udało się stworzyć zdominowanego przez jej polityków rządu oraz zdobyć w konstytuancie większości, która byłaby zdolna odwołać z urzędu Naczelnika Państwa ${ }^{12}$. Z kolei J. Piłsudski, który stronił od jednoznacznego kojarzenia go z partiami politycznymi, nie potrafił uzyskać na tyle silnej pozycji, aby samodzielnie wpływać na obronność i politykę zagraniczną kraju. J. Piłsudskiemu trudno było pogodzić się z taką sytuacją, tym bardziej, że cieszył się w dużej części polskiego społeczeństwa opinią narodowego bohatera ${ }^{13}$. Nie bez znaczenia był również fakt, na co zwrócili uwagę autorzy jednego z podręczników, że zwolenników Piłsudskiego, rozsianych po niepodległościowych partiach lewicowych i centrum, łączyło przekonanie o jego kluczowej roli w doprowadzeniu do odzyskania przez Polskę niepodległości ${ }^{14}$.

Zdecydowanie najpełniejszy obraz wydarzeń poprzedzających eskalację konfliktu politycznego w grudniu 1922 roku uczniowie szkół ponadpodstawowych mogli odnaleźć w podręczniku Grażyny Szelągowskiej z 1994 ro$\mathrm{ku}^{15}$. Zdaniem autorki w omawianym okresie konflikt endecji z obozem piłsudczykowskim odżył i uwidocznił się, gdyż minął czas, gdy jego wyciszenie było spowodowane procesem budowy zrębów polskiej państwowości. Z narracji G. Szelągowskiej wyłania się obraz sekowanego przez narodowców Na-

${ }^{11}$ A. Pankowicz, Historia 3. Polska i świat 1815-1939. Podręcznik dla klasy III liceum ogólnokształcacego, Wydawnictwa Szkolne i Pedagogiczne, Warszawa 1996, s. 341; A. Radziwiłk, W. Roszkowski, Historia 1871-1939. Podręcznik dla szkót średnich, Wydawnictwo Szkolne PWN, Warszawa 2000, s. 281.

12 A. Pankowicz, op. cit., s. 341; A. Radziwiłł, W. Roszkowski, op. cit., s. 281.

13 B. Burda, B. Halczak, R.M. Józefiak, M. Szymczak, Historia najnowsza. Historia 3. Zakres rozszerzony. Podręcznik dla liceum ogólnokształcącego, Wydawnictwo Pedagogiczne OPERON, Wydanie pierwsze, Gdynia 2005, s. 96.

${ }_{14}$ J. Choińska-Mika, P. Skibiński, P. Szlanta, K. Zielińska, Historia. Część 3. Poznać, zrozumieć. Podręcznik dla liceum i technikum, zakres podstawowy, Wydawnictwa Szkolne i Pedagogiczne, Warszawa 2009, s. 91.

15 G. Szelągowska, Historia. Dzieje nowożytne i najnowsze 1870-1939. Podręcznik dla klasy III liceum ogólnokształcącego, Wydanie czwarte, Wydawnictwa Szkolne i Pedagogiczne, Warszawa 1997, s. 288. Opracowanie to, podobnie jak większość analizowanych na potrzeby artykułu, było wznawiane w kolejnych latach, przez co w znaczący sposób rosła liczba uczniów korzystających z niego w toku szkolnej edukacji historycznej. 
czelnika Państwa. Działacze i sympatycy ruchu narodowego, którzy mieli przypisywać sobie główną rolę w procesie odzyskania przez Polskę niepodległości, dążyli w jej ocenie do szybkiego przeprowadzenia wyborów parlamentarnych, które pozwoliłby na zdobycie większości w sejmie i utworzenie stabilnego rządu. Równolegle z tym postulatem atakowano J. Piłsudskiego przy okazji sporu o obsadę stanowisk rządowych, która to kompetencja, jak napisał autorka, formalnie należała do Piłsudskiego. G. Szelągowska, o czym wspomniano już wcześniej, odnotowała, że spór toczył się również o kierunki polityki zagranicznej oraz kredyty dla Wojska Polskiego, których domagał się Naczelnik Państwa. W swoim wykładzie, dając wyraźnie do zrozumienia, po której stronie sporu lokuje swoje sympatie, autorka odnotowała, że pojawiające się już w 1921 roku ostre konflikty społeczne, strona przeciwna J. Piłsudskiemu próbowała rozwiązywać przy użyciu represji. Prawica, jak napisała, opierała się również próbom kreowania rządów przez J. Piłsudskiego ${ }^{16}$.

Zaistniałą sytuację, w części opracowań szkolnych, starano się usprawiedliwiać. Służyło temu podkreślanie faktu, że po długim okresie niewoli Polacy dopiero rozpoczynali naukę demokracji ${ }^{17}$. Sporo krytycznych uwag, na kartach podręczników, sformułowano w tym kontekście pod adresem konstytucji marcowej. Najczęściej krytykowano zapisaną w ustawie zasadę proporcjonalności w wyborach do sejmu, która sprawiła, że dwuizbowy parlament, po raz pierwszy, wybrany w listopadzie 1922 roku był mocno podzielony. Konstytucję, jak napisali autorzy jednego podręczników dla liceum, „zaaplikowano” nieprzygotowanemu do zaawansowanej demokracji polskiemu społeczeństwu. Konstytucja nie pasowała ponadto do polskich realiów, przez co stała się źródłem problemów wewnętrznych ${ }^{18}$. Konsekwencją tego stanu rzeczy była trudność z wyłonieniem większości, która byłaby zdolna do stworzenia gabinetu ze stabilnym zapleczem w parlamencie ${ }^{19}$. Podkreślano,

16 Ibidem, s. 289.

${ }_{17}$ M. Gładysz, Historia II. Część 2: Okres międzywojenny i II wojna światowa. Podręcznik dla klasy drugiej liceum i technikum. Zakres podstawowy i rozszerzony, Wydanie trzecie, Gdańskie Wydawnictwo Oświatowe, Gdańsk 2007, s. 74-75.

18 J. Kochanowski, P. Matusik, op. cit., s. 47, 344. W pierwszej z wymienionych kwestii autorzy podkreślili, że konstytucja marcowa była podobnie niedostosowana do polskich realiów, jak konstytucja Republiki Weimarskiej do niemieckich.

19 A. Radziwiłł, W. Roszkowski, op. cit., s. 281; J. Kochanowski, P. Matusik, op. cit., s. 344; T. Małkowski, J. Rześniowiecki, Historia III. Podręcznik dla klasy III gimnazjum, Wydanie siódme, Gdańskie Wydawnictwo Oświatowe, Gdańsk 2008, s. 143. 
że w okresie nieograniczonego obowiązywania konstytucji marcowej (1921-1926) cechą charakterystyczną życia politycznego II Rzeczypospolitej była częsta zmiana rządów ${ }^{20}$. Nie zabrakło opinii wyrażanych wprost, że była hamulcem w sprawnym rządzeniu krajem ${ }^{21}$. Dla części autorów źródłem problemów było przeniesienie na polski grunt francuskich rozwiązań ustrojowych, które sprzyjały niestabilności rządów i rozdrobnieniu politycznemu parlamentu ${ }^{22}$. Wskazywano, że nad życiem politycznym II Rzeczypospolitej zaciążyła kompromisowość przyjętych w ustawie rozwiązań ${ }^{23}$. W opinii Andrzeja Garlickiego, znanego historyka i jednocześnie autora podręczników, wprowadzone w konstytucji zapisy przyczyniły się do sformułowania pejoratywnego określenia sejmokracja, w sytuacji gdy nadużywania władzy można było naprawiać bez używania siły ${ }^{24}$. Znamienne, że ocena konstytucji, na mocy której w grudniu 1922 roku wybrano pierwszego prezydenta w historii Rzeczypospolitej jest mocno zróżnicowana w narracjach podręcznikowych. Obok wymienionych powyżej uwag krytycznych większość autorów szkolnych opracowań podkreślała jej demokratyczny charakter. Ponadto zwracali uwagę, że na ówczesne czasy była dokumentem odważnym i jednoznacznie podkreślającym upodmiotowienie ogółu obywateli.

Nakreślona na kartach większości opracowań sytuacja poprzedzająca wydarzenia burzliwego politycznego grudnia 1922 roku, tylko w pewnym stopniu może być jednak potraktowana jako zapowiedź poważnych problemów, z którymi miało przyjść zmierzyć się politykom i społeczeństwu II Rzeczypospolitej. Tym bardziej, że trudno jest znaleźć narrację podręcznikową, w której jednoznacznie stwierdzono, że walka na forum parlamentu o kształt poszczególnych ustaw, czy też rywalizacja na linii Naczelnik Państwa-obóz narodowy, groziła wybuchem napięć społecznych, jakie przyszło

20 G. Kucharczyk, P. Milcarek, M. Robak, Przez tysiąclecia i wieki. Cywilizacje XIX i XX wieku, kl. 3. Podręcznik dla gimnazjum, Wydawnictwa Szkolne i Pedagogiczne, Warszawa 2004, s. 170-171. Podobną opinię zob.: M. Przybyliński, Poznać przeszłość, zrozumieć dziś. Historia dzieje najnowsze 1872-2006. Poziom podstawowy i rozszerzony, Wydawnictwo Piotra Marciszuka STENTOR, Warszawa 2007, s. 133.

${ }^{21}$ W. Pronobis, Polska i świat w XX wieku. Ksiązka zatwierdzona przez Ministerstwo Edukacji Narodowej jako lektura pomocnicza dla nauczycieli i uczniów szkót średnich, Editions Spotkania, Warszawa 1990, s. 110-111.

${ }^{22}$ J. Choińska-Mika, P. Skibiński, P. Szlanta, K. Zielińska, op. cit., s. 94.

23 A. Pankowicz, op. cit., s. 337.

${ }^{24}$ A. Garlicki, Historia 1815-1939. Polska i świat, podręcznik dla III klas liceów ogólnoksztatcących, Wydawnictwo Naukowe „Scholar”, Warszawa 1998, s. 296. 
obserwować pod koniec roku. Wydaje się, że jest to niedopatrzenie, które powoduje, że obraz wydarzeń związanych z walką o urząd prezydenta oraz napięcie, które spowodowała elekcja Gabriela Narutowicza, opisywane jest w oderwaniu od emocji, które stanowiły zapowiedź poważnego kryzysu społeczno-politycznego. Historycy zwracają uwagę, a powinno być to przynajmniej zasygnalizowane w książkach szkolnych, że w połowie 1922 roku polityka polska z sali sejmowej i łamów prasy przeniosła się na ulice polskich miast $\mathrm{w}$ formie manifestacji, wieców, bójek oraz wyraźnej radykalizacji nastrojów ${ }^{25}$.

Wydarzenie, które bezpośrednio wpłynęło na gorący polityczny grudzień, stanowiły wybory do Sejmu i Senatu I kadencji. Odbyły się one w dwóch turach. Najpierw do niższej, a następnie wyższej izby parlamentu, odpowiednio w dniach 5 i 12 listopada 1922 roku$^{26}$. W opinii autorów, ale tylko jednego podręcznika, były to wybory przeprowadzone w najbardziej rzetelny spośród wszystkich w okresie międzywojennym i tym samym bez jakichkolwiek nadużyć ze strony rządzących ${ }^{27}$. W większości opracowań podano, że frekwencja wyniosła prawie 68\% i byłaby większa, gdyby ludność ukraińska z Małopolski Wschodniej oficjalnie ich nie zbojkotowała ${ }^{28}$.

Autorzy szkolnych opracowań podkreślili, że silna reprezentacja mniejszości narodowych w polskim parlamencie, które łącznie zdobyły wówczas, pomimo wspomnianego bojkotu, ponad 20\% mandatów, stworzyła zupeł-

25 „Sytuacja nie tylko w Sejmie - jak napisał Tomasz Nałęcz w publikacji z popularnej serii Dzieje narodu i państwa polskiego - ale i w kraju uległa gwałtownemu zaostrzeniu. Przesilenie gabinetowe i towarzyszące mu polityczne targowisko, coraz bardziej gorszące, trwało siódmy tydzień i opinia była coraz bardziej nim zmęczona. Nastąpił gwałtowny spadek kursu marki oraz wzrost cen. Rosnące niezadowolenie klasy robotniczej wykorzystywała zagrożona sukcesem prawicy lewica, organizując strajki i demonstracje uliczne pod hasłem Precz z Korfantym. Ale i endecja gotowa była doprowadzić rzecz do końca. Nie czekała na zapowiedziane usunięcie się Piłsudskiego i zgłosiła w Sejmie wniosek o votum nieufności dla niego" (T. Nałęcz, Rządy Sejmu..., s. 19). Zob. także: R. Wapiński, Narodowa Demokracja 1893-1939. Ze studiów nad dziejami myśli nacjonalistycznej, Wrocław 1980, s. 216.

26 A. Ajnenkiel, Historia sejmu polskiego, t. 2, cz. 2: II Rzeczpospolita, Warszawa 1989, s. 327-328.

27 J. Czubaty, D. Stola, Historia. Podręcznik klasa II. Szkoły ponadgimnazjalne. Zakres podstawowy, Wydawnictwa Szkolne i Pedagogiczne, Warszawa 2008, s. 320.

${ }^{28}$ G. Szelągowska, op. cit., s. 289; S. Sierpowski, op. cit., s. 46; A. Radziwiłł, W. Roszkowski, op. cit., s. 282; A. Pankowicz, op. cit., s. 341. Andrzej Garlicki jako jedyny wskazał, że frekwencja w wyborach do Sejmu z 5 listopada była wyższa niż do Senatu z 12 listopada 1922 roku - odpowiednio 67,7\% i 61,5\% (A. Garlicki, op. cit., s. 312). 
nie nową sytuację na scenie politycznej ${ }^{29}$. Niektórzy z nich napisali, że był to sukces niespodziewany, z czym trudno się jednak zgodzić, biorąc pod uwagę celowe przeciaganie przez Sejm Ustawodawczy prac nad ordynacją wyborczą oraz fakt, że mniejszości poszły do wyborów zblokowane, co zważywszy na ich liczbę w kraju musiało zaprocentować kilkunastoprocentowym wynikiem $^{30}$. Niestety żaden $\mathrm{z}$ autorów podręczników nie zwrócił uwagi, że stanowiło to zapowiedź poważnych konfliktów narodowościowych w II Rzeczypospolitej, skoro już na początku niepodległości żadna z polskich partii politycznych nie była w stanie pozyskać dla swoich list znaczącego poparcia przedstawicieli mniejszości narodowych. A jest to kwestia istotna, zważywszy że w ocenie polityki narodowościowej międzywojennej Polski często eksponowany jest wątek jej nieumiejętnego prowadzenia wobec mniejszości narodowych. W szczególności dotyczyło to Ukraińców i, jak się wydaje, potwierdza tezę, według której jakiekolwiek działania wobec mniejszości, zachowujące nadrzędność polskiego interesu państwowego i narodowego, a nie jednostronne ustępstwa na rzecz mniejszości były skazane na niepowodzenie. K woli ścisłości należy odnotować, że część autorów szkolnych opracowań zwróciła uwagę, że posłowie mniejszości narodowych nie byli zainteresowani w poparciu jakiejkolwiek koalicji parlamentarnej, co może być interpretowane jako działanie antypaństwowe ${ }^{31}$. Nieliczni autorzy zwrócili z kolei uwagę, że to polska większość w parlamencie, w pełni świadomie zepchnęła mniejszości na margines polityki państwa ${ }^{32}$.

$\mathrm{Z}$ narracji podręcznikowych uczniowie mogli dowiedzieć się, że obawy, które pojawiły bezpośrednio po uchwaleniu konstytucji w marcu 1921

${ }^{29}$ Także w kwestii wyników wyborów najdokładniejsze dane dotyczące liczby mandatów uzyskanych przez Blok Mniejszości Narodowych podali Stanisław Sierpowski i Andrzej Garlicki. Według przywołanych przez nich danych Blok skupiający Ukraińców, Białorusinów, Niemców, Żydów i Rosjan dostał 16\% głosów, co dało mu w Sejmie 66 mandatów. Do tej liczby, jak podkreślił autor - należy dodać 23 mandaty uzyskane przez galicyjskich syjonistów, żydowskich ludowców oraz Agrarną Ukraińską Chłopską Partię tzw. Chliborobi (A. Garlicki, op. cit., s. 311; S. Sierpowski, op. cit., s. 46-47). Zob. także: J. Kochanowski, P. Matusik, op. cit., s. 345; A. Radziwiłł, W. Roszkowski, op. cit., s. 282; M. Jastrzębska, M. Żurawski, Historia 3. Podręcznik dla klasy trzeciej gimnazjum, Wydanie drugie, Wydawnictwo Edukacyjne Wiking, Wrocław 2004, s. 43; J. Choińska-Mika, P. Skibiński, P. Szlanta, K. Zielińska, op. cit., s. 94; B. Burda, B. Halczak, R. M. Józefiak, M. Szymczak, op. cit., s. 97; M. Gładysz, op. cit., s. 75; J. Czubaty, D. Stola, op. cit., s. 320; M. Przybyliński, op. cit., s. 135.

30 T. Małkowski, J. Rześniowiecki, op. cit., s. 143.

31 J. Choińska-Mika, P. Skibiński, P. Szlanta, K. Zielińska, op. cit., s. 94.

32 A. Garlicki, op. cit., s. 312. 
roku, a dotyczące nadmiernego rozdrobnienia sceny politycznej, któremu sprzyjał przyjęty model ustrojowy z dominującą rolą parlamentu, w pełni potwierdziły się po ukonstytuowaniu Sejmu i Senatu ${ }^{33}$. Perspektywa tworzenia koalicyjnych gabinetów, przy coraz bardziej podzielonej scenie politycznej, na której równoważyły się wpływy prawicy, lewicy i centrum, zapowiadała poważne problemy przed młodą polską demokracją ${ }^{34}$. Rozdrobnienie parlamentu pogłębiał dodatkowo fakt, podkreślony w jednym z podręczników, że „[...] posłowie dość często zmieniali przynależność partyjną" 35 .

Początek prac obu izb parlamentu pokazał jednak, że stosunkowo szybko zdołano zbudować porozumienie na linii prawica, którą tworzyły Związek Ludowo-Narodowy i Stronnictwo Chrześcijańsko-Narodowe, centrum z Chrześcijańską Demokracją, oraz Polskie Stronnictwo Ludowe „Piast”, które było największym ugrupowaniem ludowym w Sejmie określanym również mianem centrowego. Efektem porozumienia był sprawny wybór marszałków obu izb. Pod koniec listopada marszałkiem Sejmu wybrano Macieja Rataja reprezentującego PSL „Piast”, a przewodniczącym izby wyższej (Senatu) dotychczasowego marszałka Sejmu Ustawodawczego Wojciecha Trąmpczyńskego reprezentanta prawicowego Związku Ludowo-Narodowego ${ }^{36}$. Taki obrót wydarzeń pozornie tylko wskazywał, że dalsze prace parlamentu, w tym wybór prezydenta oraz powołanie rządu mającego poparcie sejmowej większości, będą przebiegać w atmosferze politycznej rywalizacji, ale nie otwartego konfliktu. Na wynikający z tego problem uwagę uczniów zwrócili autorzy podręcznika z serii Poznać zrozumieć, którzy stwierdzili, że prawicę i PSL „Piast” poważnie dzieliła kwestia reformy rolnej, a przede wszystkim sprzeciw wobec ich zbliżenia otwarcie manifestowany przez lewicę i Józefa Piłsudskiego ${ }^{37}$.

Zdaniem autorów większości syntez historycznych, jak i podręczników szkolnych, wybór prezydenta stał się pierwszą okazją do politycznej kon-

${ }^{33}$ M. Gładysz, op. cit., s. 75.

${ }^{34}$ G. Szelągowska, op. cit., s. 290; T. Małkowski, J. Rześniowiecki, op. cit., s. 143.

35 S. Sierpowski, op. cit., s. 47.

${ }^{36}$ A. Garlicki, op. cit., s. 312; A. Pankowicz, op. cit., s. 342. Na temat szukania porozumienia między wspomnianymi ugrupowaniami zob. także: G. Kucharczyk, P. Milcarek, M. Robak, op. cit., s. 171 .

${ }^{37}$ J. Choińska-Mika, P. Skibiński, P. Szlanta, K. Zielińska, op. cit., s. 94; J. Czubaty, D. Stola, op. cit., s. 320 . 
frontacji ${ }^{38}$. Dla przebiegu wyboru głowy państwa, którego zgodnie z konstytucją dokonać miało Zgromadzenie Narodowe, kluczowe znaczenie miała jednak decyzja podjęta na kilka dni przed elekcją przez Józefa Piłsudskiego. Naczelnik Państwa postanowił nie kandydować w wyborach ${ }^{39}$. Deklaracja ta jak można przeczytać w omawianych opracowaniach wywołała ogólne zaskoczenie $^{40}$. Uzasadnienie decyzji J. Piłsudskiego, mówiące o ograniczeniu kompetencji prezydenta przez ustawę zasadniczą, przywołane zostało przez wielu autorów szkolnych narracji podręcznikowych ${ }^{41}$. Znamienne, że w tym

38 R. Kaczmarek, Historia Polski 1914-1989, Warszawa 2010, s. 137; G. Szelągowska, op. cit., s. 290; J. Choińska-Mika, P. Skibiński, P. Szlanta, K. Zielińska, op. cit., s. 94. Nie brakuje jednak podręczników, w których autorzy wybór prezydenta uznali jedynie jako kolejny etap tworzenia instytucji państwa polskiego (M. Jastrzębska, M. Żurawski, op. cit., s. 43).

39 Podczas zorganizowanego 4 grudnia 1922 roku spotkania w Pałacu Radziwiłłowskim z posłami PSL „Piast”, Narodowej Partii Robotniczej oraz PSL „Wyzwolenie”, na które byli też zaproszeni posłowie ugrupowań prawicowych, ale, co warto podkreślić, już nie posłowie żydowscy, J. Piłsudski oznajmił, że nie będzie kandydował na urząd prezydenta. W uzasadnieniu, używając plastycznych porównań, powiedział wówczas m.in.: „Proszę wysłuchać rady. Na mnie proszę nie głosować. Proszę wybrać człowieka, który by miał ciężki chód, lecz lekką rękę. Z bagien i trzęsawisk trzeba się wydobywać. Człowiek o lekkim chodzie przechodzi je za szybko i nie pomaga przez to innym. Natomiast lekka ręka jest potrzebna dla wprowadzenia kompromisu. Kompromis jest nieszczęśliwym słowem. W wielu umysłach łączy się ono z pojęciem zdrady. Tymczasem kompromis jest ściśle związany z istotą demokratyzmu. Polega on bowiem na uznaniu, że nie tylko moja wola jednej strony, czy chęć jej jest uprawniona do przejawienia się w państwie, lecz że równe prawa ma wola i chęć innych. Kompromis jest ułatwiony, gdy i jego konieczność, narzucająca się sama przez się, urasta w zasadę szanowania innych, jako współobywateli. [...] Kompromis taki za pomocą wpływu, jaki przy sprawowaniu rządu ma zastrzeżony Prezydent Rzeczypospolitej, wprowadzić może stopniowo lekka ręka, a nie ciężka, która szybko idzie do przymusu. Dlatego nie radzę zatrzymać się na kandydaturach o wybitnie partyjnym zabarwieniu. Nie radzę stawiać przyszłego Pana prezydenta Rzeczypospolitej w ciężki konflikt między obowiązkami, jakie ma w stosunku do wszystkich - i tylko do niektórych. Żegnając się z panami i zamykając księgę wspólnej naszej historii [...] Chcę wyrazić serdeczną wdzięczność za tę pomoc i zapewnić, że w miłym wspomnieniu zachowam zawsze wszystkich tych, którzy przeszli ze mną choć chwilę razem po historycznej drodze - drodze piaszczystej i błotnistej, drodze, jaką w ostatnich dwóch latach przebyłem" (J. Piłsudski, Pisma zbiorowe, t. 5, Warszawa 1937, s. 295-296). O tej decyzji Naczelnika Państwa informują uczniów autorzy zdecydowanej większości podręczników przeznaczonych dla uczniów ze szkół ponadpodstawowych i ponadgimnazjalnych.

${ }^{40}$ J. Czubaty, D. Stola, op. cit., s. 320.

${ }^{41}$ S. Sierpowski, op. cit., s. 47; J. Choińska-Mika, P. Skibiński, P. Szlanta, K. Zielińska, op. cit., s. 94; A. Garlicki, op. cit., s. 312; M. Jastrzębska, M. Żurawski, op. cit., s. 44. Narracja wymienionych autorów zgodna jest z opiniami historyków. W tym gronie szczególną pozycję zajmuje Andrzej Garlicki występujący w obu rolach. Zob. m.in.: A. Garlicki, Józef Pitsudski 1867-1935, Warszawa 1990, s. 247. W tym miejscu należy jednak postawić pytanie, nad którym nie- 
kontekście stosunkowo rzadko podkreślali, że decyzja Marszałka, w istotny sposób nie wpłynęła na spadek temperatury politycznych sporów w kraju ${ }^{42}$. Wyjątek w tej materii stanowi podręcznik Grażyny Szelągowskiej, która jako jedna z nielicznych, zwróciła uwagę uczniów, że na rosnącą temperaturę wydarzeń politycznych w Polsce, wpływały dwa istotne czynniki. Po pierwsze J. Piłsudski miał znaczące grono zwolenników w ugrupowaniach sejmowej lewicy i centrum, którzy nie zamierzali bezczynnie obserwować jego, jak się wydaje taktycznego i chwilowego odsunięcia od najważniejszych spraw i stanowisk w kraju. Po drugie nie bez wpływu na przebieg wypadków pozostała analiza sytuacji na Półwyspie Apenińskim, gdzie w konsekwencji marszu na Rzym władzę przejął Benito Mussolini i jego faszystowskie ugrupowanie ${ }^{43}$.

Okoliczności elekcji Gabriela Narutowicza na urząd prezydenta w dniu 9 grudnia 1922 roku prezentowane są w podręcznikach w sposób obszerny, choć z uwagi na ograniczoną liczbę miejsca pozbawione swoistych niuansów $^{44}$. Taka sytuacja powoduje, że młode osoby, kończące szkołę średnią/ ponadgimnazjalną, w znacznym stopniu ugruntowują swój pogląd na temat wyboru pierwszego prezydenta przez pryzmat indywidualnej opinii autora podręcznika, chyba że problem inaczej naświetlił nauczyciel prowadzący lekcję ${ }^{45}$, a ta nierzadko może znacznie odbiegać od zaproponowanej przez

stety historycy zastanawiają się zbyt rzadko. Czy J. Piłsudski, który w swoim życiu wielokrotnie udowadniał, że nie boi się grać o najwyższą stawkę, licytować bardzo wysoko, wówczas w grudniu 1922 roku, tak ważnym momencie dla niego, jego zwolenników i idei, które mu przyświecały, postanowił odejść od stołu gry, zanim jeszcze rozpoczęła się decydująca rozgrywka? Jest to naturalnie możliwe, ale przy założeniu, z którym szczególnie trudno godzą się sympatycy Marszałka, że w kluczowych momentach nie wytrzymywał napięcia, a więc w chwili złożenia dymisji na ręce premiera Witosa w sierpniu 1920 roku, czy po rozmowie na Moście Poniatowskiego z prezydentem Stanisławem Wojciechowskim w maju 1926 roku.

${ }^{42}$ Trafnie sytuację powstałą w wyniku tej decyzji ocenił Janusz Pajewski, który stwierdził, że deklaracja Piłsudskiego o tym, że o prezydenturę nie będzie się ubiegać, „[...] z jednej strony rozjaśniała sytuację, z drugiej ją skomplikowała. Rozjaśniła sytuację przeciwnikom marszałka”. Zdecydowanie skomplikowała sytuację w centrum i na lewicy. Więcej zob.: J. Pajewski, W. Łazuga, Gabriel Narutowicz. Pierewszy prezydent Rzeczypospolitej, Warszawa 1993, s. 127.

${ }^{43} \mathrm{~W}$ podręczniku podana została informacja, że po elekcji Narutowicza pod ambasadą Włoch w Warszawie odbywała się manifestacja na cześć Mussoliniego, który był stawiany za wzór walki o prawa narodu włoskiego (G. Szelągowska, op. cit., s. 290). Informację taką zamieścili również autorzy innych podręczników (A. Radziwiłł, W. Roszkowski, op. cit., s. 283).

${ }^{44} \mathrm{~W}$ gronie analizowanych podręczników można wskazać i takie, w których data wyborów prezydenta przez Zgromadzenie Narodowe została podana błędnie. Dla przykładu 8 zamiast 9 grudnia 1922 roku (A. Pankowicz, op. cit., s. 342).

45 Badanie tego problemu $\mathrm{w}$ odniesieniu do różnych zagadnień omawianych $\mathrm{w}$ toku 
autora podręcznika. Właściwie nie było w tym żadnego problemu, gdyby nie fakt, że od uczniów kończących naukę zewnętrznym egzaminem maturalnym, w szkołach ponadgimnazjalnych, tj. 3-letnim liceum i 4-letni technikum, wymaga się w arkuszu z historii konkretnej wiedzy, a w przypadku rozprawki, wręcz przysłowiowego „wstrzelenia w klucz”, który rozbieżności, o których za chwilę nieco więcej generalnie nie dopuszcza.

Kwestią, która już na wstępie powinna być uczniom wyjaśniona, a tak niestety nie jest, i to również w naukowych opracowaniach, jest sam fakt wysunięcia kandydatury Gabriela Narutowicz, profesora, intelektualisty, wywodzącego się z rodziny szlacheckiej przez radykalne ugrupowanie chłopskie jakim było Polskie Stronnictwo Ludowe „Wyzwolenie”. Kwestii tej nie podejmuje niestety żaden $\mathrm{z}$ autorów podręczników. Taką sytuację w pewnym stopniu może tłumacz fakt, że sami historycy nie są zgodni w kwestii okoliczności, w jakich pojawiła się kandydatura G. Narutowicza. Wyjaśnienia jej można spróbować poprzez wspomniane w artykule spotkanie z 4 grudnia 1922 roku, na którym Józef Piłsudski ogłosił, że nie będzie kandydatem w wyborach prezydenckich. W spotkaniu tym, podobnie jak i inni parlamentarzyści PSL „Wyzwolenie” uczestniczył jego lider Stanisław Thugutt. Wyartykułowany wówczas przez Naczelnika Państwa apel o poszukiwanie kandydata, bez jednoznacznie politycznego zabarwienia, S. Thugutt odczytał jak się wydaje dosłownie i postanowił na własną rękę znaleźć kandydata. W ten sposób mógł pojawić się pomysł wysunięcia kandydatury Gabriela Narutowicza $^{46}$. Biografowie G. Narutowicza zwracają uwagę, że pewne znaczenie, aczkolwiek jest to bardzo trudne do udokumentowania, mogła mieć jego przynależność do loży masońskiej, w której „bratem” był również Stanisław Thugutt ${ }^{47}$. Trzeci element, o którym warto wspomnieć, to prawdopodobna kalkulacja Thugutta zakładającą, że kandydatura G. Narutowicza spodoba się Marszałkowi, dlatego że tak jak on pochodził z kresów północno-wschodnich, a ściśle ze Żmudzi i podobnie jak Piłsudski był jednoznacznie krytycznie ustosunkowany do Rosji. Nie można zapomnieć również o łączących Piłsudskiego i Narutowicza, wprawdzie dalekich, ale zawsze koligacjach rodzinnych ${ }^{48}$.

szkolnej edukacji historycznej jest jednak niezwykle trudne i przez to rzadko podejmowane w sposób profesjonalny przez dydaktyków historii.

46 Zob. A. Wójcik, Myśl polityczna Stanisława Thugutta (1873-1941), Lublin 1992, s. 20.

${ }^{47}$ J. Pajewski, W. Łazuga, op. cit., s. 134-135.

48 Brat Gabriela Narutowicza Stanisław (1862-1932) był mężem Joanny Narutowicz 
Zamieszanie, które warto wyjaśniać uczniom dotyczy również informacji podanej w części opracowań, według której G. Narutowicz od samego początku był kandydatem posłów i senatorów mniejszości narodowych ${ }^{49}$. A to nie było to prawdą, gdyż w chwili zgłaszania kandydatur w imieniu bloku mniejszości narodowych Ozjasz Thon przedstawił kandydaturę Jana Baudouina de Courtenay, a nie G. Narutowicza, którego kandydaturę wysunął jak wspomniano klub PSL „Wyzwolenie”, a ściśle poseł, późniejszy senator, Jan Woźnicki. Potwierdzeniem poparcia udzielonego przez mniejszości narodowe G. Narutowiczowi, ale dopiero w kolejnych głosowaniach, było uzyskanie przez Jana Baudouina de Courtenay w pierwszym głosowaniu niemal wszystkich głosów posłów i senatorów mniejszości narodowych ${ }^{50}$. Przerzucenie głosów na Narutowicza nastąpiło więc dopiero po tym, jak przedstawiciele mniejszości uznali, że ich polityczna manifestacja, mająca na celu pokazanie obecności, a de facto siły w polskim parlamencie, odniosła pożądany skutek. Zachowanie to i fakt przeniesienia poparcia na kandydata PSL „Wyzwolenie" nie uszło uwadze posłów z prawej strony sceny politycznej ${ }^{51}$.

de domo Billewiczówny (1868-1948), która tak jak matka Józefa Piłsudskiego pochodziła z zasłużonej i znanej na Litwie rodziny Bilewiczów.

49 Taką informację można znaleźć m.in. w: A. Pankowicz, op. cit., s. 342. Tego błędu nie popełnił już jednak Andrzej Garlicki na kartach swojego autorskiego podręcznika.

${ }^{50}$ Jan Niecisław Baudouin de Courtenay otrzymał w nim 103 głosy. Historycy okresu międzywojennego zwracają uwagę, że wysunięcie jego kandydatury miało charakter demonstracyjny, gdyż od samego początku było wiadomo, że nie będzie on w stanie uzyskać wystarczającego poparcia. J. N. Baudouin de Courtenay był wybitnym językoznawcą, pochodzącym z francuskiej rodziny, która spolonizowała się jeszcze w XVIII stuleciu (C. Brzoza, Polska w czasach niepodległości i II wojny światowej, Kraków 2001, s. 106).

51 Warto podkreślić, że część polskich historyków, nota bene dalekich od sympatii do obozu polskiej prawicy, krytycznie oceniła zachowanie przedstawicieli mniejszości narodowych podczas głosowania w Zgromadzeniu Narodowym 9 grudnia 1922 roku. „Analiza piątego rozstrzygającego - głosowania wykazuje, że Narutowicz zawdzięczał wybór głosom mniejszości narodowych. Fakt ten wymaga rozważenia. [...] Nasuwa się pytanie, co by się stało, gdyby posłowie mniejszości nie wzięli udziału w Zgromadzeniu Narodowym. Byłby to z ich strony niewątpliwie akt antypaństwowy. Jakie wrażenia musiałoby to wywrzeć w świecie? A chwila była trudna. Rząd polski zabiegał właśnie o uznanie granic wschodnich. Demonstracja mniejszości narodowych utrudniłaby te starania. W wyborach stanęło przeciwko sobie dwóch polskich szlachciców. $\mathrm{Na}$ jednego z nich musiały paść głosy posłów mniejszościowych. Ale przedstawiciele mniejszości popełnili poważny błąd. Za błąd ten zapłaciły mniejszości, zwłaszcza Żydzi. Zapłaciła i Polska! Gdyby posłowie mniejszości mieli instynkt polityczny i rozeznanie sytuacji, rozłożyliby swe głosy na poszczególnych kandydatów. Nie byłoby wówczas mowy o narzuceniu elekta przez czynniki niepolskie. Ale Blok Mniejszości Narodowych chciał pokazać siłę. I pokazał! Odniósł zwycięstwo, ale było to zwycięstwo pyrrusowe! Jego skutkiem był wzrost nacjonalizmu polskiego, 
Kolejna kwestia zasługująca na podniesienie w toku szkolnej edukacji historycznej i jednocześnie stosunkowo trudna do wyjaśnienia, ale mająca znaczenie w kontekście napięć, do których doszło w kolejnych dniach grudnia 1922 roku, dotyczy odpowiedzi na pytanie: Na ile Gabriel Narutowicz był $\mathrm{w}$ chwili elekcji osobą rozpoznawalną przez opinię publiczną, a na ile postacią nieznaną, czy wręcz anonimową w Polsce? Element powodujący chaos pojęciowy w tej materii tworzą między innymi przywoływane w podręcznikach informacje mówiące, że G. Narutowicz był nie tylko znanym inżynierem, profesorem Politechniki w Zurychu, który wiele lat spędził w Szwajcarii (obywatelstwo tego kraju uzyskał w 1895 roku), ale również przez ponad dwa lata ministrem w polskich rządach (1920-1922), najpierw robót publicznych, a następnie spraw zagranicznych ${ }^{52}$. Andrzej Garlicki podkreślił w swoim opracowaniu, że G. Narutowicz sprawdził się w pracy państwowej ${ }^{53}$. Takie przedstawienie postaci jednoznacznie wskazuje uczniom, że G. Narutowicz nie był postacią anonimową, która stała na uboczu wielkiej polityki i na najwyższe stanowisko państwowe została wybrana w wyniku, nieoczekiwanego dla większości sejmowej, jak i polskiego społeczeństwa zbiegu okoliczności ${ }^{54}$. Inaczej problem przedstawili nieliczni autorzy, w tym Jan Wróbel, który napisał, że G. Narutowicz był mało znanym w Polsce profesorem, który od wielu lat mieszkał w Szwajcarii ${ }^{55}$. Z wypowiedzi tej obok nieścisłości sugerującej, że w chwili elekcji G. Narutowicz nadal mieszkał w Szwajcarii, jasno wynika, że nie był postacią szczególnie popularną, co nie budzi większego sprzeciwu w konfrontacji z opiniami historyków. J. Wróbel podkreślił ponadto, że wybór Narutowicza na

w szczególności antysemityzmu" (J. Pajewski, Budowa Drugiej Rzeczypospolitej 1918-1926, Kraków 1995, s. 200-201). W zbliżony sposób, choć nie tak wnikliwie, sytuacja została tak nakreślona w jednym opracowaniu A. Garlickiego, op. cit., s. 312).

52 T. Glubiński, Historia 8. Trudny wiek XX, Wydawnictwa Szkolne i Pedagogiczne, Warszawa 1993, s. 105; s. G. Szelaggowska, op. cit., s. 290; A. Radziwiłł, W. Roszkowski, op. cit., s. 283; T. Małkowski, J. Rześniowiecki, op. cit., s. 143; M. Gładysz, op. cit., s. 75, 81; B. Burda, B. Halczak, R. M. Józefiak, M. Szymczak, op. cit., s. 97; J. Choińska-Mika, P. Skibiński, P. Szlanta, K. Zielińska, op. cit., s. 95; J. Czubaty, D. Stola, op. cit., s. 320. J. Bednarz, M. Litwinienko, K. Zapała, Historia 3. Podręcznik dla gimnazjum, Wydawnictwo Pedagogiczne OPERON, Gdynia 2007, s. 64.

53 A. Garlicki, op. cit., s. 312.

54 Biografowie Narutowicza podkreślają wręcz, że nie był on popularny nawet w łonie partii, która wysunęła jego kandydaturę, a więc jak można mówić o jego popularności w społeczeństwie polskim (J. Pajewski, W. Łazuga, op. cit., s. 135).

55 J. Wróbel, op. cit., s. 198. 
prezydenta był zupełnie niespodziewany. Część autorów, którzy wymienili pełnione przez Narutowicza funkcje i zajmowane stanowiska, wspomniała jednak, że w chwili wyboru na najwyższy urząd w państwie G. Narutowicz był osobą „szerzej nieznaną"

Zablokowanie głosami lewicy, centrum i mniejszości narodowych kandydata prawicy Maurycego Zamoyskiego, człowieka zasłużonego w dziele odbudowy niepodległości Polski, zostało bardzo źle odebrano przez środowiska narodowe w Polsce ${ }^{57}$. W tym kontekście najczęściej podkreślano w podręcznikach, że prawicę oburzył nie tyle sam fakt porażki M. Zamoyskiego, co fakt, że przegrał z osobą, którą poparli posłowie i senatorowie z bloku mniejszości narodowych ${ }^{58}$. Z problemem tym związana jest kwestia przedstawienia w podręcznikach podczas wyborów w Zgromadzeniu Narodowym roli posłów Polskiego Stronnictwa Ludowego „Piast”. Otóż w części opracowań, to właśnie ich postawa podczas głosowania, czyli poparcie kandydatury G. Narutowicza lub też wstrzymanie się od głosu, miało de facto kluczowe znaczenie dla ostatecznego wyniku elekcji ${ }^{59}$. Według części autorów o ich postawie przesądził fakt, że nie mogli zaakceptować kandydata (M. Zamoyskiego), który był wielkim właścicielem ziemskim ${ }^{60}$. Analizując problem, Anna Radziwiłł i Wojciech Roszkowski zwrócili również uwagę na postawę dwudziestu posłów i senatorów Narodowej Partii Robotniczej, którzy także niechętnie odnieśli się do kandydatury M. Zamoyskiego $^{61}$. Zdecydowanie najlepiej w całej sytuacji znaleźli się autorzy podręcznika wydanego przez gdyński OPERON, którzy napisali, że na wynik wyborów, w których zwyciężył G. Narutowicz, wpłynęła postawa zarówno

56 J. Choińska-Mika, P. Skibiński, P. Szlanta, K. Zielińska, op. cit., s. 95.

${ }^{57}$ M. Gładysz, op. cit., s. 75; J. Choińska-Mika, P. Skibiński, P. Szlanta, K. Zielińska, op. cit., s. 94-95.

58 „O zwycięstwie Narutowicza - napisał wprost Andrzej Garlicki - zdecydowały głosy mniejszości narodowych. Ci parlamentarzyści nie mogli głosować na kandydata nacjonalistycznej prawicy, zdecydowali się więc poprzeć człowieka, który wiele lat mieszkał w wielojęzycznej Szwajcarii i pozbawiony był narodowych uprzedzeń” (A. Garlicki, op. cit., s. 313). Zob. także: A. Pankowicz, op. cit., s. 342.

59 G. Szelągowska, op. cit., s. 290; A. Radziwiłł, W. Roszkowski, op. cit., s. 283; J. Wróbel, op. cit., s. 198; J. Czubaty, D. Stola, op. cit., s. 320; M. Przybyliński, op. cit., s. 135.

${ }^{60}$ M. Gładysz, op. cit., s. 75.

${ }^{61}$ Dla autorów wspomnianego podręcznika zasadnym było bardzo wyraźnie podkreślić, że „[...] o wyborze Narutowicza zadecydowała przede wszystkim postawa "Piasta»" (A. Radziwiłk, W. Roszkowski, op. cit., s. 283). 
Bloku Mniejszości Narodowych, jak i części elektorów PSL „Piast”62. Konieczność podkreślania wspomnianych okoliczności wydaje się mieć istotne znaczenie, gdyż jej brak w zestawieniu z informacjami podanymi przez wszystkie podręczniki, a mówiącymi, że prawica protestowała przeciwko kandydatowi mniejszości, wybranemu przeciwko polskiej większości, fałszuje obraz wydarzeń, w którym rola obrotowych, bezideowych i działających w imię własnego, bardzo wąsko pojętego interesu klasowego, umyka z pola widzenia ${ }^{63}$.

W tym miejscu warto zaproponować autorom podręczników wykorzystanie fragmentu biografii Gabriela Narutowicza, napisanej przez Janusza Pajewskiego i Waldemara Łazugę. Czytamy w niej m.in.:

Zgromadzenie Narodowe stanęło przed głosowaniem piątym i ostatecznym. Otwarcie posiedzenia po przerwie opóźniało się, gdyż puste były ławy „Piasta”. Klub obradował burzliwie. Witos usiłował przeprowadzić uchwałę wzywającą piastowców do oddania głosów na ordynata Maurycego Zamoyskiego. Nie zdołał przemóc opozycji. Była to chyba jego pierwsza znacząca przegrana w Klubie. Po długiej chwili piastowcy weszli na salę, na ich czele kroczył Witos col viso rabbuiato. Była to istotnie gruba gra. Była to gra nie tylko o osobę pierwszego prezydenta, ale i o zasadę, na jakiej go wybierano. Czy równe są, zgodnie z konstytucją wszystkie głosy poselskie, czy też według teorii państwa narodowego o najważniejszych sprawach Rzeczypospolitej rozstrzygać mają jedynie Polacy. Oczy wszystkich zwróciły się na „Piasta”, tam leżała decyzja, a leżała w znacznej mierze w rękach wójta z Wierzchosławic ${ }^{64}$.

Powyższy fragment z powodzeniem może zostać potraktowany jako ilustracja problemu, ale również wyborny przykład źródła historiograficznego.

${ }^{62}$ B. Burda, B. Halczak, R. M. Józefiak, M. Szymczak, op. cit., s. 97.

${ }^{63}$ Wydaje się, że problem ten warto naświetlać młodzieży, szczególnie jeśli w kontekście reformy programów nauczania historii dla szkół ponadgimnazjalnych, od września 2012 roku, tak duży nacisk położono na kształcenie obywatelskie. Zasadne byłoby zachęcenie uczniów do przeanalizowania na lekcji lub w ramach zadania domowego postawy reprezentantów „polskiej wsi”, choćby tylko na forum polskiego parlamentu w trzech okresach: 1919-1939, 1947-1989 oraz po roku 1989.

${ }^{64}$ J. Pajewski, W. Łazuga, op. cit., s. 139-140. 
Wydarzenia, które rozegrały się pomiędzy 9 a 16 grudnia 1922 roku, tj. datą elekcji G. Narutowicza na prezydenta a jego zamordowaniem przez Eligiusza Niewiadomskiego w gmachu „Zachęty”, stanowiły kulminacyjny moment politycznego napięcia. Wspomniane już kontrowersje związane $\mathrm{z}$ wyborem G. Narutowicza głosami mniejszości narodowych w szybkim tempie trafiły do szerokiej opinii publicznej. Stało się tak za sprawą brutalnych i bez wątpienia mocno krzywdzących osobę prezydenta elekta artykułów zamieszczanych w prasie obozu narodowego oraz licznych tytułach z nim sympatyzujących. Okoliczności te odnotowują wszystkie analizowane opracowania ${ }^{65}$. Na podstawie podręczników stworzyć można długą listę zarzutów, obelg, a nawet gróźb, których obiektem stał się G. Narutowicz. Pisano o klęsce katolickiej Polski, triumfie wrogów Polski - mniejszości i masonów, wyzwaniu rzuconym narodowi polskiemu, prezydencie „wybranym przez niepolską większość"66, „antypolskim i masońskim prezydencie” ${ }^{67}$, „żydowskim elekcie” ${ }^{68}$, „żydowskim pachołku i narodowej hańbie”, ${ }^{69}$, „żydowskim prezydencie”70, „niewierzącym elekcie, który niemal całe życie spędził poza Polską"11, wreszcie ,ich prezydencie"72.

Dla wielu autorów, szczególnie tych, którzy przygotowali podręczniki dla uczniów szkół średnich (ponadpodstawowych, obecnie ponadgimnazjlanych) istotne znaczenie miało przywołanie burzliwych wydarzeń, jakie rozegrały się na ulicach Warszawy w dniu zaprzysiężenia prezydenta. W tym miejscu należy zwrócić uwagę, że w analizowanych podręcznikach podane zostały trzy różne daty dzienne tego wydarzenia tj. 11, 12 lub 14 grudnia

${ }^{65}$ W. Pronobis, op. cit., s. 111; G. Szelągowska, op. cit., s. 290; S. Sierpowski, op. cit., s.48; T. Glubiński, op. cit., s. 105; A. Garlicki, op. cit., s. 314; A. Pankowicz, op. cit., s. 342; A. Radziwiłł, W. Roszkowski, op. cit., s. 283; J. Wróbel, op. cit., s. 198-199; T. Małkowski, J. Rześniowiecki, op. cit., s. 143; M. Gładysz, op. cit., s. 75; M. Jastrzębska, M. Żurawski, op. cit., s. 44; B. Burda, B. Halczak, R.M. Józefiak, M. Szymczak, op. cit., s. 97; G. Kucharczyk, P. Milcarek, M. Robak, op. cit., s. 171; J. Bednarz, M. Litwinienko, K. Zapała, op. cit., s. 64; J. Czubaty, D. Stola, op. cit., s. 320; J. Choińska-Mika, P. Skibiński, P. Szlanta, K. Zielińska, op. cit., s. 95;

${ }^{66}$ G. Kucharczyk, P. Milcarek, M. Robak, op. cit., s. 171; J. Choińska-Mika, P. Skibiński, P. Szlanta, K. Zielińska, op. cit., s. 95.

${ }^{67}$ G. Szelagowska, op. cit., s. 290.

68 A. Garlicki, op. cit., s. 314; G. Szelągowska, op. cit., s. 290.

${ }^{69}$ T. Małkowski, J. Rześniowiecki, op. cit., s. 143.

70 J. Czubaty, D. Stola, op. cit., s. 320.

71 A. Pankowicz, op. cit., s. 342.

72 A. Radziwiłł, W. Roszkowski, op. cit., s. 283. 
1922 roku $^{73}$. Atmosferę i rozwój wypadków w stolicy szczególnie wnikliwe opisano w podręcznikach $\mathrm{z}$ lat dziewięćdziesiątych, przygotowanych z myślą o czteroletnim liceum ${ }^{74}$. Warto $\mathrm{w}$ tym miejscu przytoczyć kilka zamieszczonych w nich narracji, gdyż plastycznie opisują szczyt politycznego rozgorączkowania. W opracowaniu Stanisława Sierpowskiego można przeczytać, że uroczystość zaprzysiężenia prezydenta zbojkotowali prawicowi posłowie i senatorowie, a „Część z nich agitowała na licznych wiecach i nacjonalistycznych demonstracjach. Podburzone tłumy nie przepuszczały udających się na posiedzenie; kilku posłów i senatorów zostało poturbowanych. Wokół sejmu doszło do zamieszek ulicznych, w których jedna osoba poniosła śmierć, a 26 zostało rannych"75. S. Sierpowski podkreślił również, że jadącego w odkrytym powozie na uroczystość G. Narutowicza obrzucono śniegiem, a w trudnej drodze do gmachu Sejmu nie chciał mu towarzyszyć profesor Julian Nowak, ówczesny premier, czym nie wystawił sobie najlepszego świadectwa. Podobny opis zamieścił w swoim podręczniku Andrzej Garlicki, który dodatkowo podał, że podczas zamieszek poturbowano Ignacego Daszyńskiego i 87-letniego senatora Bolesława Limanowskiego, a od kuli rewolwerowej zginął młody robotnik, socjalista. W narracji A. Garlicki podkreślił również „niemrawą” postawę policji, która nie potrafiła skutecznie interweniować przeciwko sprawcom wspomnianych zajśćc ${ }^{76}$. Część autorów zwróciła uwagę uczniów, że na ulicach Warszawy doszło wówczas do otwartego starcia socjalistów i sympatyków Józefa Piłsudskiego ze zwolennikami Narodowej Demokracji ${ }^{77}$.

Gabriela Narutowicza spotykały także innego rodzaju przykrości. Były wśród nich także listy zawierające obelgi, ale i pogróżki pobicia, a nawet śmierci ${ }^{78}$. W tym kontekście, w pojedynczych opracowaniach, odnotowano, że w kraju zaczęły krążyć plotki o możliwości przeprowadzenia zamachu

${ }^{73}$ Data 11 grudnia występuje w podręcznikach: T. Glubiński, op. cit., s. 105; G. Szelaggowska, op. cit., s. 290; A. Radziwiłł, W. Roszkowski, op. cit., s. 283; B. Burda, B. Halczak, R.M. Józefiak, M. Szymczak, op. cit., s. 97; J. Choińska-Mika, P. Skibiński, P. Szlanta, K. Zielińska, op. cit., s. 95; 12 grudnia podaje m. in.: S. Sierpowski, op. cit., s. 48 . Z kolei datę 14 grudnia podał: W. Pronobis, op. cit., s. 111.

74 A. Pankowicz, op. cit., s. 342.

75 S. Sierpowski, op. cit., s. 48.

76 A. Garlicki, op. cit., s. 314.

77 J. Choińska-Mika, P. Skibiński, P. Szlanta, K. Zielińska, op. cit., s. 95.

78 W. Pronobis, op. cit., s. 111; G. Szelągowska, op. cit., s. 290; A. Radziwiłt, W. Roszkowski, op. cit., s. 283. 
stanu przez siły prawicowe ${ }^{79}$. Ta sytuacja spowodować miała, jak mogli przeczytać uczniowie korzystający z podręcznika m.in. G. Szelągowskiej, uzasadnione obawy J. Piłsudskiego o bezpieczeństwo wewnętrzne kraju, a nawet wybuch wojny domowej ${ }^{80}$. Dla części autorów istotnym było podkreślenie, że 14 grudnia doszło do oficjalnego przekazania władzy prezydentowi przez ustępującego z urzędu Naczelnika Państwa ${ }^{81}$. Cytowano nawet słowa J. Piłsudskiego, które podczas uroczystego śniadania wydanego z tej okazji skierował do G. Narutowicza ${ }^{82}$.

„Tragicznym finałem gorączki nacjonalistycznej” jeden z autorów określił wydarzenia, które rozegrały się tuż po godzinie dwunastej 16 grudnia 1922 roku w gmachu Towarzystwa Zachęty Sztuk Pięknych w Warszawie ${ }^{83}$. W tym miejscu warto podkreślić, że w podręcznikach wydarzenie to opisane zostało przy użyciu określeń o mocno zróżnicowanym poziomie emocjonalnego ładunku. Część autorów napisała, że prezydent został zamordowany ${ }^{84}$, inni z kolei, że został zastrzelony ${ }^{85}$, lub też padł ofiarą zamachu ${ }^{86}$, padł od kul zamachowca ${ }^{87}$, zginął od kilku strzałów z rewolweru ${ }^{88}$, zginął z ręki zamachowca ${ }^{89}$. W jeszcze innych uczniowie mogli przeczytać, że został zamordowany strzałem z pistoletu przez malarza, „[...] ideowo związanego z endecją, nota bene człowieka niezrównoważonego psychicznie” ${ }^{90}$, lub też „[...] Niewiadomski oddał trzy celne strzały z bliskiej odległości do prezydenta.

79 A. Pankowicz, op. cit., s. 342; T. Małkowski, J. Rześniowiecki, op. cit., s. 143.

80 G. Szelągowska, op. cit., s. 290.

81 G. Szelągowska, op. cit., s. 291.

82 T. Małkowski, J. Rześniowiecki, op. cit., s. 144.

83 S. Sierpowski, op. cit., s. 48. Andrzej Garlicki napisał z kolei, że 16 grudnia 1922 roku „posiew nienawiści wydał owoce” (idem. op. cit., s. 314), a Grażyna Szelągowska o „nacjonalistycznej nagonce, która przyniosła w końcu tragiczny rezultat (G. Szelągowska, op. cit., s. 291). Zob. także: M. Jastrzębska, M. Żurawski, op. cit., s. 44; T. Małkowski, J. Rześniowiecki, op. cit., s. 143-144; M. Gładysz, op. cit., s. 75; J. Wróbel, op. cit., s. 199; B. Burda, B. Halczak, R. M. Józefiak, M. Szymczak, op. cit., s. 97; J. Bednarz, M. Litwinienko, K. Zapała, op. cit., s. 64;

${ }^{84}$ G. Szelagowska, op. cit., s. 291; M. Gładysz, op. cit., s. 75.

85 M. Jastrzębska, M. Żurawski, op. cit., s. 44; B. Burda, B. Halczak, R. M. Józefiak, M. Szymczak, op. cit., s. 97; J. Bednarz, M. Litwinienko, K. Zapała, op. cit., s. 64; M. Przybyliński, op. cit., s. 135; J. Choińska-Mika, P. Skibiński, P. Szlanta, K. Zielińska, op. cit., s. 95.

${ }^{86}$ T. Glubiński, op. cit., s. 105.

87 G. Kucharczyk, P. Milcarek, M. Robak, op. cit., s. 172.

88 J. Wróbel, op. cit., s. 199.

89 J. Czubaty, D. Stola, op. cit., s. 320-321.

90 A. Radziwiłł, W. Roszkowski, op. cit., s. 284. 
Zgon nastąpił w ciągu kilku chwil”91, bądź też „Trzy strzały z pistoletu fanatycznego zwolennika endecji ugodziły go w plecy. Gabriel Narutowicz zmarł niemal natychmiast"92.

Eligiusz Niewiadomski, w większości opracowań, został przedstawiony jako powiązany $z$ endecją: fanatyczny nacjonalista ${ }^{93}$, zwolennik endecji $^{94}$, sympatyk Narodowej Demokracji ${ }^{95}$, malarz związany z obozem narodowym ${ }^{96}$. W części podręczników autorzy ograniczyli się do podania informacji, że zamachowiec był Polakiem ${ }^{97}$ lub tylko malarzem ${ }^{98}$. W niektórych uznano za stosowne, aby zaznaczyć, że dochodzenie wykazało, że zamach nie był skutkiem spisku' ${ }^{99}$. W innych z kolei, że choć obóz narodowy nie ponosił bezpośredniej winy za zamach, to jednak odpowiadał za histeryczną kampanię antyprezydencką ${ }^{100}$. W części podręczników określono E. Niewiadomskiego jako „niezrównoważonego psychicznie sympatyka lub fanatyka endecji ${ }^{101}$. Warto zwrócić uwagę na ten aspekt sprawy, gdyż kwestia tego, na ile zabójca prezydenta był osobą zdrową, a na ile chorą psychicznie, po dzień dzisiejszy nie jest rozstrzygnięta i budzi spore emocje.

W nielicznych opracowaniach osobie zamachowca poświęcono nieco więcej miejsca. Do grona takich opracowań należy m.in. podręcznik gdyńskiego Operonu dla uczniów klasy trzeciej gimnazjum, wydany z myślą o trzecim etapie edukacji przed reformą programową obowiązującą od września 2009 roku. W rubryce $C z y$ wiesz, że... zamieszczono w nim następującą notkę: „Eligiusz Niewiadomski był malarzem, ilustratorem książek i krytykiem sztuki. Jako ochotnik walczył wraz ze swoim synem w wojnie polsko-bolszewickiej. Po zamachu na Narutowicza nie bronił się przed aresztowa-

91 A. Garlicki, op. cit., s. 314.

92 T. Małkowski, J. Rześniowiecki, op. cit., s. 144.

93 M. Jastrzębska, M. Żurawski, op. cit., s. 44.

${ }_{94}$ J. Bednarz, M. Litwinienko, K. Zapała, op. cit., s. 64.

95 W. Pronobis, op. cit., s. 111; T. Glubiński, op. cit., s. 105-106; B. Burda, B. Halczak, R.M. Józefiak, M. Szymczak, op. cit., s. 97;

${ }_{96}$ M. Przybyliński, op. cit., s. 135.

97 G. Kucharczyk, P. Milcarek, M. Robak, op. cit., s. s 171-172.

98 A. Pankowicz, op. cit., s. 342; G. Szelaggowska, op. cit., s. 291.

99 B. Burda, B. Halczak, R. M. Józefiak, M. Szymczak, op. cit., s. 97.

${ }^{100}$ J. Choińska-Mika, P. Skibiński, P. Szlanta, K. Zielińska, op. cit., s. 95; A. Garlicki, op. cit., s. 314 .

101 A. Garlicki, op. cit., s. 314; M. Gładysz, op. cit., s. 75; J. Czubaty, D. Stola, op. cit., s. 321 . 
niem, a podczas rozprawy przyznawał, że zasłużył na karę śmierci. Skazano go na rozstrzelanie. Wyrok wykonano, a ostatnie słowa Niewiadomskiego brzmiały Ginę za Polskę, która gubi Pitsudski"102. Informacja o procesie zabójcy prezydenta G. Narutowicza, jego osądzeniu, skazaniu na śmierć oraz straceniu zamieszczona została również w kilku innych podręcznikach ${ }^{103}$. W narracjach podręcznikowych pojawiły się informacje mówiące, że zbrodniczy czyn E. Niewiadomskiego miał w Polsce licznych obrońców ${ }^{104}$, a on sam wielu sympatyków. Podkreślano, że radykalne środowiska nacjonalistyczne uznały E. Niewiadomskiego za bohatera-męczennika, a następnie otoczyły jego osobę kultem ${ }^{105}$. Anna Radziwiłł i Wojciech Roszkowski podkreślili, że zamordowanie prezydenta nie od razu otrzeźwiło zwolenników endecji. W powstrzymaniu szerzenia kultu E. Niewiadomskiego zmuszony był interweniować nawet Episkopat Polski ${ }^{106}$. Andrzej Garlicki zwrócił jednak uwagę, że kult E. Niewiadomskiego pomagali tworzyć działaczom skrajnej prawicy „niektórzy księża”, czyniąc z zamachowca „zbawcę ojczyzny”. Pomimo odprawiania mszy w jego intencji oraz składania kwiatów na jego grobie nie zdołano jednak wykreować z E. Niewiadomskiego powszechnie akceptowanego bohatera narodowego ${ }^{107}$. Podobnie całą sytuację oceniła G. Szelągowska, według której margines sił nacjonalistycznych, które usiłowały wykreować kult E. Niewiadomskiego, był stosunkowo wąski ${ }^{108}$.

Dla części autorów istotne było podkreślenie, że sytuację opanowano stosunkowo szybko. W opinii jednego nich: „Wobec powszechnego wzburzenia Polska stanęła na skraju wojny domowej” i tylko dzięki rozsądkowi przywódców partyjnych zdołano uniknać dalszego rozlewu krwi ${ }^{109}$. Pisano, że niezwłocznie zastosowano konstytucyjne procedury, zgodnie z którymi obowiązki głowy państwa przejął Marszałek Sejmu - Maciej Rataj ${ }^{110}$. Nie-

${ }^{102}$ J. Bednarz, M. Litwinienko, K. Zapała, op. cit., s. 64.

103 A. Garlicki, op. cit., s. 314; T. Małkowski, J. Rześniowiecki, op. cit., s. 144; B. Burda, B. Halczak, R. M. Józefiak, M. Szymczak, op. cit., s. 98.

104 S. Sierpowski, op. cit., s. 48.

105 B. Burda, B. Halczak, R. M. Józefiak, M. Szymczak, op. cit., s. 98.

106 A. Radziwiłł, W. Roszkowski, op. cit., s. 284.

107 A. Garlicki, op. cit., s. 314.

108 G. Szelągowska, op. cit., s. 291.

109 M. Gładysz, op. cit., s. 75.

110 W. Pronobis, op. cit., s. 111; T. Glubiński, op. cit., s. 105-106; A. Garlicki, op. cit., s. 314; G. Szelągowska, op. cit., s. 291; A. Radziwiłł, W. Roszkowski, op. cit., s. 284; M. Jastrzębska, M. Żurawski, op. cit., s. 44. 
stety tylko w kilku podręcznikach wspomniano, że bezpośrednio po zabójstwie prezydenta socjaliści szykowali kontrdemonstrację i rozprawę z prawica ${ }^{111}$. W tym miejscu warto podkreślić, że takie plany miała tylko część działaczy socjalistycznych, a w ich zablokowaniu kluczową rolę odegrał nie kto inny tylko czołowy polityk Polskiej Partii Socjalistycznej Ignacy Daszyński ${ }^{112}$.

Istotne znaczenie miało również, choć odnotowane tylko w części opracowań, powołanie nowego rządu, na czele którego stanął zawodowy wojskowy - gen. Władysław Sikorski ${ }^{113}$. Jednym z pierwszych posunięć nowego prezesa Rady Ministrów, jak podkreśliła część autorów, było wprowadzenie stanu wyjątkowego w stolicy i aresztowanie najbardziej zapalczywych agitatorów ${ }^{114}$. Według A. Garlickiego, który w tej opinii jest odosobniony, ostre słowa, a wręcz groźby nowego premiera były skierowane „[...] raczej przeciwko piłsudczykom i lewicy niż przeciwko prawicy, która przerażona sytuacją sama nawoływała do spokoju"115.

Jako element stabilizacji sytuacji politycznej wymieniany jest w opracowaniach również wybór następcy G. Narutowicza. W wyniku głosowania przeprowadzonego 20 grudnia 1922 roku, a więc cztery dni po tragicznej śmierci G. Narutowicza, prezydentem został Stanisław Wojciechowski. W narracjach podręcznikowych podkreślono, że tym razem, choć nowego prezydenta poparły dokładnie te same ugrupowania polityczne co G. Narutowicza, nie doszło do protestów ze strony sił prawicowych ${ }^{116}$. Witold Pronobis ocenił to jako kolejną porażkę prawicy ${ }^{117}$. Okoliczności wyborów drugiego prezydenta szczegółowo ze szczegółami przedstawił m.in. A. Garlicki.

111 A. Garlicki, op. cit., s. 314; J. Czubaty, D. Stola, op. cit., s. 321.

112 Taką precyzyjną informację można przeczytać jedynie w podręcznikach Andrzeja Garlickiego oraz Anny Radziwiłł i Wojciecha Roszkowskiego.

113 W. Pronobis, op. cit., s. 111; A. Garlicki, op. cit., s. 314; A. Pankowicz, op. cit., s. 342; G. Szelagowska, op. cit., s. 291; M. Gładysz, op. cit., s. 75.

114 S. Sierpowski, op. cit., s. 49; A. Radziwiłł, W. Roszkowski, op. cit., s. 284; J. Czubaty, D. Stola, op. cit., s. 321.

115 A. Garlicki, op. cit., s. 314.

116 S. Sierpowski, op. cit., s. 48. Zob. także: G. Szelągowska, op. cit., s. 291; T. Glubiński, op. cit., s. 106; A. Pankowicz, op. cit., s. 342; A. Radziwiłł, W. Roszkowski, op. cit., s. 284; T. Małkowski, J. Rześniowiecki, op. cit., s. 144; M. Gładysz, op. cit., s. 75; B. Burda, B. Halczak, R.M. Józefiak, M. Szymczak, op. cit., s. 98; J. Bednarz, M. Litwinienko, K. Zapała, op. cit., s. 64; J. Czubaty, D. Stola, op. cit., s. 321; M. Przybyliński, op. cit., s. 135; J. Choińska-Mika, P. Skibiński, P. Szlanta, K. Zielińska, op. cit., s. 95.

117 W. Pronobis, op. cit., s. 111. 
Napisał on, że po ogłoszeniu wyników, w którym Wojciechowski uzyskał 298 głosów i już w pierwszym głosowaniu pokonał kandydata prawicy Kazimierza Morawskiego, który uzyskał 221 głosów, z ław lewicy pod adresem prawicy padł okrzyk: „Kiedy go zabijecie?”. „Prawica - konkludował autor opracowania - nie zamierzała jednak Wojciechowskiego zabijać, ani nawet atakować. Osiągnęła bowiem swój cel: szansa na koalicję lewicy, centrum i mniejszości narodowych została przekreślona. Więcej nawet - posłowie mniejszości narodowych zostali właściwie na zawsze wyeliminowani z parlamentarnej gry politycznej" ${ }^{118}$.

W części opracowań autorzy pokusili się o wnikliwą analizę konsekwencji jakie spowodowało zamordowanie prezydenta G. Narutowicza. W tym gronie wyróżnia się ponownie podręcznik A. Garlickiego. Napisał on, że najgłębsze wnioski z zamordowania prezydenta wyciągnęli polscy socjaliści. „To wówczas - czytamy w jego opracowaniu - powstało Towarzystwo Uniwersytetu Robotniczego (TUR), które wkrótce powołało organizację młodzieżową (OMTUR) i Czerwone Harcerstwo. Socjaliści uważali bowiem, że system demokratyczny obronić może tylko społeczeństwo świadome jego wartości, a także, że socjalizm mogą realizować jedynie ludzie do tego przygotowani”"119. Obok wymienionych inicjatyw A. Garlicki wymienił cały szereg działań, które po grudniu 1922 roku podjęte zostały przez polskich socjalistów.

Opisując wydarzenia gorącego politycznego grudnia 1922 roku autorzy podręczników postanowili użyć wyrazistych i zapadających w pamięć uczniów określeń. Tadeusz Glubiński autor podręcznika dla uczniów ósmej klasy szkoły podstawowej napisał, że „Śmierć prezydenta Narutowicza była dramatem całej Rzeczypospolitej” i jednocześnie wydarzeniem bez precedensu w dziejach Polski" ${ }^{120}$. G. Szelągowska, obarczając moralną odpowiedzialnością za zabójstwo G. Narutowicza endecję, stwierdziła, że czyn ten „wstrząsnął zdecydowaną większością opinii publicznej”"121. Podobnie zaistniałą sytuację ocenili A. Radziwiłł i W. Roszkowski, którzy napisali, że „Zabójstwo Narutowicza było szokiem i zaciążyło na stosunkach politycznych w całym okresie międzywojennym" ${ }^{122}$. S. Sierpowski, podsumowując opis

118 A. Garlicki, op. cit., s. 316.

119 Ibidem, s. 315.

120 T. Glubiński, op. cit., s. 105.

121 G. Szelągowska, op. cit., s. 291.

122 A. Radziwiłł, W. Roszkowski, op. cit., s. 284. 
grudniowych wydarzeń, stwierdził, że „W kraju panowała przygnębiająca atmosfera”, ale „Rachuby Piłsudskiego na ponowne przejęcie całej władzy celem uspokojenia sytuacji - zawiodły” ${ }^{22}$. Zdaniem S. Sierpowskiego „Demokracja parlamentarna, choć nie bez ofiar i wielkich dramatów, przetrwała pierwszy wielki kryzys" ${ }^{124}$. Podobną opinię wyraził A. Garlicki, który napisał, że „W tych pierwszych godzinach i dniach po zabójstwie prezydenta polska demokracja zdała egzamin i to tym trudniejszy, że zrodziła się ledwie przed kilku laty”125. W. Pronobis zwrócił uwagę, że „Paradoksem pierwszego w dziejach Polski zabójstwa politycznego tak wysokiego rangą męża stanu był fakt, że ofiarą stał się nie dyktator, gwałcący wolność obywateli, a człowiek, który był uosobieniem demokratycznych metod sprawowania władzy"126. J. Wróbel wybory pierwszego prezydenta II Rzeczypospolitej określił mianem „okrutnej lekcji”, która pokazała, do czego prowadzi roznamiętnienie nastrojów politycznych. W jego ocenie choć zdołano rozładować napięcie polityczne, to jednak „[...] wydarzenia związane z wyborem i zabójstwem Narutowicza w pewien sposób rzuciły cień na całą demokrację. Endecji na zawsze zapamiętano, że to jej histeryczne protesty natchnęły zabójcę żądzą czynu dla ratowania Polski" ${ }^{127}$. W opinii Mikołaja Gładysza zabójstwo pierwszego prezydenta spotęgowało antagonizmy polityczne między Polakami. Ugrupowania lewicowe, obarczając prawicę odpowiedzialnością za morderstwo, ostro protestowały przeciwko podejmowanych w późniejszym okresie próbom stworzenia centroprawicowych koalicji rządowych ${ }^{128}$. Małgorzata Jastrzębska i Przemysław Żurawski uznali, że „Zabójstwo głowy państwa było szokiem dla społeczeństwa i polskich elit politycznych" ${ }^{129}$. Jerzy Kochanowski i Przemysław Matusik podkreślili, że zamordowanie prezydenta G. Narutowicza było najtragiczniejszą konsekwencją wewnętrznych problemów odradzającego się państwa, którą spowodowało nieprzygotowanie polskiego społeczeństwa do zaawansowanej demokracji ${ }^{130}$. Autorzy podręcznika wydanego przez WSiP dla gimnazjum,

\footnotetext{
123 S. Sierpowski, op. cit., s. 48.

124 Ibidem, s. 49.

125 A. Garlicki, op. cit., s. 315.

126 W. Pronobis, op. cit., s. 111.

127 J. Wróbel, op. cit., s. 198-199.

128 M. Gładysz, op. cit., s. 75-76.

${ }_{129}$ M. Jastrzębska, M. Żurawski, op. cit., s. 44.

130 J. Kochanowski, P. Matusik, op. cit., s. 47.
} 
podsumowując fragment zatytułowany Pierwszy prezydent Rzeczypospolitej zabity przez zamachowca, napisali, że wydarzenie z 16 grudnia było ciemną plamą na historii Polski, gdyż dotąd nie zdarzyło się, by głowa państwa polskiego zginęła z polskich rąk. „Na szczęście, nigdy potem się to nie powtórzyło"131.

O poziomie podręczników szkolnych do nauczania historii decyduje jednak nie tylko narracja autorska, ale również ich obudowa dydaktyczna. Tworzą ją teksty źródłowe, głównie historyczne, stosunkowo rzadko historiograficzne, ikonografia oraz bloki ćwiczeniowe dla uczniów. Podejmując się próby syntetycznego omówienia tych materiałów, w wybranych na potrzeby artykułu podręcznikach, już na wstępie należy podkreślić, że zarówno wśród źródeł pisanych, jak i ikonograficznych można dokonać klasyfikacji, która pokazuje dominujące tendencje. I tak źródła pisane w analizowanych podręcznikach reprezentowane są w odniesieniu do omawianej problematyki poprzez bardzo zróżnicowane materiały. Dominują źródła opisowe nad normatywnymi. Dobitnie ilustruje to okoliczność, w której aż w trzech podręcznikach przygotowanych dla liceum wykorzystano fragmenty wspomnień Marszałka Sejmu Macieja Rataja opisujące wydarzenia z 11 grudnia 1922 roku, czyli dnia zaprzysiężenia prezydenta G. Narutowicza ${ }^{132}$. Do źródeł pisanych należy również wiersz Kazimierza Wierzyńskiego Szafot, który w swoim podręczniku zamieścili Anna Radziwiłł i Wojciech Roszkowski ${ }^{133}$. Źródła normatywne reprezentuje jedynie zamieszczony w podręczniku dla gimnazjum wydawnictwa Wiking Komunikat Kancelarii Cywilnej Prezydenta Rzeczypospolitej Polskiej o zabójstwie Gabriela Narutowicza z 16 grudnia 1922 roku $^{134}$.

131 G. Kucharczyk, P. Milcarek, M. Robak, op. cit., s. 172.

132 Do tekstów autorzy podręczników sformułowali pytania problemowe dotyczące źródeł agresywnych zachowań posłów w sejmie (G. Szelągowska, op. cit., s. 310-311), określenia politycznych zwolenników i przeciwników Gabriela Narutowicza oraz roli, jaką w opisanych przez Macieja Rataja wydarzeniach starał się odegrać Józef Piłsudski (J. Czubaty, D. Stola, op. cit., s. 329), postawy posłów prawicy, nastrojach panujących na ulicach Warszawy w dniu zaprzysiężenia prezydenta, a także problemów proceduralnych, z jakimi musiał radzić sobie w zaistniałej sytuacji marszałek sejmu (M. Gładysz, op. cit., s. 83).

133 A. Radziwiłł, W. Roszkowski, op. cit., s. 284.

${ }^{134}$ Z dokumentu uczniowie mogli dowiedzieć się w szczegółach o ostatnich minutach życia prezydenta, okolicznościach jego śmierci oraz procedurach, jakie zostały wdrożone po jego zamordowaniu przez Eligiusza Niewiadomskiego (M. Jastrzębska, M. Żurawski, op. cit., s. 43). 
Wśród źródeł ikonograficznych zdecydowanie dominują fotografie prezydenta Gabriela Narutowicza. Najczęściej zamieszczano w podręcznikach fotografię przedstawiającą G. Narutowicza przy biurku już jako urzędującego prezydenta ${ }^{135}$. W analizowanych podręcznikach odnajdujemy również inne fotografie przedstawiające G. Narutowicza. Wykonano je jednak w okresie, gdy nie pełnił jeszcze obowiązków prezydenta ${ }^{136}$. Ponadto w jednym z podręczników zamieszczono portret G. Narutowicza, ukazujący go jako urzędującego prezydenta ${ }^{137}$. Także tylko w jednym opracowaniu zamieszczono fotografię przedstawiającą Józefa Piłsudskiego i Gabriela Narutowicza siedzących przy małym okrągłym stoliku. Wykonano ją najprawdopodobniej 14 grudnia 1922 roku podczas uroczystości przekazania obowiązków przez Naczelnika Państwa wybranemu pięć dni wcześniej prezydentowi ${ }^{138}$. W kil$\mathrm{ku}$ podręcznikach zamieszczono również pojedyncze fotografie przedstawiające kolejno: gmach Towarzystwa Zachęty Sztuk Pięknych w Warszawie z podpisem, że jest to miejsce, w którym zamordowano prezydenta G. Narutowicza ${ }^{139}$, straż przy trumnie zamordowanego prezydenta Gabriela Narutowicza ${ }^{140}$ oraz Plac Zamkowy w Warszawie podczas pogrzebu prezyden$\mathrm{ta}^{141}$. W kontekście wydarzeń grudniowych pojawia się również fotografia wybranego na urząd prezydenta po zamordowaniu G. Narutowicza Stanisława Wojciechowskiego ${ }^{142}$.

135 A. Pankowicz, op. cit., s. 342; M. Jastrzębska, M. Żurawski, op. cit., s. 43. Ta sama fotografia, tyle że prezentująca zbliżenie G. Narutowicza, zamieszczona została również w kilku innych opracowaniach (T. Glubiński, op. cit., s. 105; S. Sierpowski, op. cit., s. 47; A. Radziwiłł, W. Roszkowski, op. cit., s. 283; J. Bednarz, M. Litwinienko, K. Zapała, op. cit., s. 64; B. Burda, B. Halczak, R. M. Józefiak, M. Szymczak, op. cit., s. 97; J. Czubaty, D. Stola, op. cit., s. 320).

136 A. Garlicki, op. cit., s. 313.

137 J. Choińska-Mika, P. Skibiński, P. Szlanta, K. Zielińska, op. cit., s. 95.

138 G. Szelagowska, op. cit., s. 291.

139 T. Małkowski, J. Rześniowiecki, op. cit., s. 143.

140 G. Kucharczyk, P. Milcarek, M. Robak, op. cit., s. 171.

${ }_{141}$ T. Małkowski, J. Rześniowiecki, op. cit., s. 144.

142 T. Glubiński, op. cit., s. 106; A. Garlicki, op. cit., s. 315; S. Sierpowski, op. cit., s. 48; A. Radziwiłł, W. Roszkowski, op. cit., s. 284; M. Jastrzębska, M. Żurawski, op. cit., s. 44; B. Burda, B. Halczak, R. M. Józefiak, M. Szymczak, op. cit., s. 98; J. Bednarz, M. Litwinienko, K. Zapała, op. cit., s. 64; J. Czubaty, D. Stola, op. cit., s. 321. W pojedynczych opracowaniach zamieszczono również obraz przedstawiający drugiego prezydenta Rzeczypospolitej (T. Małkowski, J. Rześniowiecki, op. cit., s. 144). 
Lista naukowych publikacji poświęconych wydarzeniom gorącego politycznego grudnia 1922 roku jest stosunkowo długa. Po 1989 roku bibliografia pozycji dotyczących tylko i wyłącznie okoliczności śmierci Gabriela Narutowicza wzbogaciła się o kilkanaście tytułów. Ich autorzy zaprezentowali zróżnicowanie interpretacje poszczególnych aspektów grudniowych wydarzeń ${ }^{143}$. Reprezentatywne dla dominującej części oceny prezentuje, przywołany na wstępie artykułu Marek Andrzejewski, który konsekwentnie podkreśla, że zamordowanie G. Narutowicza stanowiło dla wielu Polaków szok, a wydarzenie samo w sobie, tak obce polskiej tradycji politycznej, winno skłaniać do refleksji nad niebezpieczeństwem jakie dla życia politycznego wszelkiej maści fanatyzmowi politycznych i religijnych ${ }^{144}$. Drugą grupę ocen oddaje publikacja Zofii Waszkiewicz, w której dokonała analizy i syntetycznego omówienia najważniejszych ustaleń historyków zajmujących się okolicznościami burzliwych wydarzeń i stwierdziła, że śmierć G. Narutowicza w najmniejszym nawet stopniu nie wpłynęła na wyciszenie sporu o Polskę, jaki toczyła prawica z J. Piłsudskim ${ }^{145}$. W ostatnim czasie okoliczności burz-

${ }^{143}$ Do ważniejszych publikacji wydanych na przestrzeni ostatnich kilkudziesięciu lat, obok wymienionych już wcześniej w przypisach opracowań, należy zaliczyć: Z. Kaczmarek, Trzej prezydenci II Rzeczypospolitej, Warszawa 1988, s. 11-65; Gabriel Narutowicz pierwszy prezydent Rzeczypospolitej (1922), [w:] Prezydenci Polski, red. A. Ajnenkiel, Warszawa 1991, s. 33-38; J. Pajewski, W. Łazuga, op. cit., s. 119-182; P. Rybarczyk, „Dziennik Bydgoski” wobec wyboru Gabriela Narutowicza na prezydenta Rzeczypospolitej Polskiej w 1922 roku, „Kronika Bydgoska” 2003, t. 25, s. 104-128; M. Sołtysik, Czarna godzina polskiej demokracji, „Palestra” 2003, nr 2, s. 166-172; M. Mazur, Media endeckie wobec wyboru i śmierci pierwszego prezydenta RP Gabriela Narutowicza, „Dzieje Najnowsze” 2010, R. XLII, nr 2, s. 51-69; P. Dąbrowski, Zabójstwo Prezydenta Gabriela Narutowicza - proces Eligiusza Niewiadomskiego, „Imponderabilia. Biuletyn Piłsudczykowski” 2011, nr 2, s. 144-165.

${ }_{144}$ M. Andrzejewski, Kilka uwag o Gabrielu Narutowiczu..., s. 52. Autor, co należy podkreślić, nie ulega jednak w tej materii, częstej u niektórych historyków, tendencji do jednoznacznego wskazywania potencjalnego zagrożenia dla demokracji tylko ze strony ugrupowań prawicowych, choć nie ma też obiekcji przed krytyką, nota bene w pełni uzasadnioną, irracjonalnego sprzeciwu części posłów Zjednoczenia Chrześcijańsko-Narodowego wobec pomysłu nadania w 1992 roku jednej sal w gmachu Sejmu imienia Gabriela Narutowicza (M. Andrzejewski, Gabriel Narutowicz i jego rezygnacja..., s. 144).

145 „Prezydent Gabriel Narutowicz - można przeczytać w przywołanym artykule - stał się pionkiem w grze, drugorzędną i wówczas, i dzisiaj postacią dramatu. I był to tylko dramat jego samego i jego rodziny, bo tak naprawdę nigdy nie stał się dramatem - Polski. [...] Narutowicz zapłacił najwyższą cenę za trwający już w latach zaborów konflikt między obozem niepodległościowym, skupionym wokół J. Piłsudskiego, chociaż nie miał on monopolu na walkę o niepodległość Rzeczypospolitej, oraz obozem prawicy, w którym prym wiodła założona w 1898 roku Narodowa Demokracja z jej duchowym przywódcą R. Dmowskim, rzecznikiem nowocze- 
liwych wydarzeń grudnia 1922 roku przywołane zostały również w popularnych opracowaniach historycznych. Tu warto wymienić m.in. tekst Zbrodnia $w$ Zachęcie, który autor Sławomir Koper zamieścił w książce koncentrującej się na burzliwych wydarzeniach z dziejów międzywojennej Polski ${ }^{146}$. Popularny charakter ma również wydana w 2004 roku antologia tekstów dotyczących Gabriela Narutowicza opracowana przez Mariana Marka Drozdowskiego $^{147}$.

Temat burzliwych politycznych wydarzeń grudnia 1922 roku, a w szczególności zabójstwa prezydenta G. Narutowicza, to także jedno z tych zagadnień, któremu sporo uwagi poświęcili nie tylko historycy. Niemal każdego roku w połowie grudnia, a już obowiązkowo przy okazji okragłych rocznic zamachu z 16 grudnia 1922 roku, łamy popularnych tytułów prasowych wypełniają artykuły poświęcone prezydentowi G. Narutowiczowi, E. Niewiadomskiemu oraz ówczesnej atmosferze społeczno-politycznej w kraju. Autorami tych publikacji nierzadko są osoby na co dzień niezajmujące się historią. Lista opublikowanych przez nich tekstów jest bardzo długa. W zdecydowanej większości dominują materiały ostro potępiające rozpętaną przez obóz narodowy nagonkę na prezydenta G. Narutowicza ${ }^{148}$. Osobną grupę

snego nacjonalizmu i ograniczonej demokracji” (Z. Waszkiewicz, Śmierć prezydenta Gabriela Narutowicza - Zabójstwo na zlecenie czy tragiczny finat walki o władze, [w:] Narodowa Demokracja XX-XX wiek (Koncepcje - Ludzie - Działalność), red. T. Sikorski, A. Wątor, Szczecin 2008, s. 627, 628). Problematyką wyborów prezydenckich 1922 roku oraz śmierci Narutowicza Zofia Waszkiewicz zajmuje się od wielu lat, co potwierdzają m.in. opublikowane przez nią artykuły (eadem, Społeczeństwo Torunia wobec wyboru i zabójstwa prezydenta Gabriela Narutowicza. $Z$ dziejów walki endecji o władzę, „Rocznik Toruński” 1985, t. 17, s. 125-170; eadem, Wybór $i$ zabójstwo prezydenta Gabriela Narutowicza w ocenie ambasadora wtoskiego Francesco Tomassiniego, [w:] Toruńskie Studia Polsko-Wtoskie (Studi Polacco-Italiani di Toruń), red. A. Tomczak, Toruń 1986, 143-175; eadem, Wptyw prasy prawicowej na przebieg walki o urzad prezydenta II Rzeczypospolitej w 1922 roku, [w:] Polska i jej sasiedzi w czasach najnowszych, red. M. Wojciechowski, Toruń 1995, s. 89-103).

146 S. Koper, Afery i skandale Drugiej Rzeczypospolitej, Warszawa 2011, s. 35-63. Opracowanie to, choć znacznie skromniejsze objętościowo, przypomina swoim układem publikacje: M. Ruszczyc, Pierwszy prezydent Gabriel Narutowicz, Warszawa 1967, s. 196-278; idem, Strzaty $w$ Zachęcie, Katowice 1987; F. Bernaś, Gabriel Narutowicz, Warszawa 1979, s. 64-95; idem, Ofiary fanatyzmu, Warszawa 1987, s. 115-188.

${ }_{147}$ Gabriel Narutowicz. Prezydent RP we wspomnieniach, relacjach i dokumentach, wybór i opracowanie M. M. Drozdowski, Warszawa 2004.

148 A. Osęka, Powrót sprawy Narutowicza, „Gazeta Wyborcza” [dalej: GW], nr 295 z 16.12.1992, s. 16; M. Turski, Ofiara i zabójca, „Polityka”, nr 11 z 15.03.1997, s. 72-74; RS, Rocznica śmierci Narutowicza, GW nr 292 z 16.12.1997, s. 2; A. Szczypiorski, 1922-1997, 
stanowią artykuły piętnujące próby uczczenia w III Rzeczypospolitej postaci E. Niewiadomskiego ${ }^{149}$. Nie brakuje tekstów, które odchodzą jednak od tej utartej już sztampy i próbują pokazać wydarzenia w szerszym kontekście lub też z innej perspektywy ${ }^{150}$.

$\mathrm{Na}$ uwagę zasługują również popularne, często polemiczne publikacje zwarte, których autorzy w sposób bezpośredni lub przy okazji opisywania innych wydarzeń odnoszą się do tytułowego grudnia 1922 roku. Znaczenia tych publikacji nie można przeceniać w kontekście ich wpływu na kształt edukacji historycznej, ale błędem byłoby ich lekceważenie, biorąc pod uwagę fakt, że do części z nich sięgnęli zapewne nauczyciele historii, a za ich inspiracją sami uczniowie. W tym zestawieniu szczególną uwagę zwraca szkic Anny Bojarskiej Dwaj panowie N. (Wokót Niewiadomskiego), zamieszczony w skromnej objętościowo publikacji zwartej pod wymownym tytułem $\mathrm{Za}$ strzelony jadłospis. Czyli trochę mitologii polskiej. Autorka w nasyconym emocjami tekście, który, jak podkreśliła, zaważył również na jej życiu osobistym, „rozprawiła się” nie tylko z E. Niewiadomskim, ale i mitem, jaki narósł wokół zbrodniczego czynu, który dokonał. Dla Bojarskiej „zbawienny wstrząs”, jaki miał się dokonać w polskim społeczeństwie w wyniku zabójstwa pierwszego prezydenta, był mitem, który powtarzały przedwojenne i powojenne podręczniki krajowe i emigracyjne. Lansowaną w ten sposób wersję wyda-

GW, nr 292 z 16.12.1997, s. 24; T. Urzykowski, K. Lasocki, Śmierć prezydenta. 75 rocznica śmierci Gabriela Narutowicza, GW (Gazeta Stołeczna), nr 292 z 16.12.1997, s. 8; W. Kalicki, Zawada usunięta, GW, nr 294 z 17.12.1997, dod. „Duży Format”, nr 48, s. 14; W. Sobecki, Tragiczny finat zbrodniczej inspiracji, „Dziś” 2002, nr 12, s. 88-92; A. Garlicki, Śmierć prezydenta, „Polityka”, nr 49 z 7.12.2002, s. 74-76; J. S. Majewski, Pierwszy prezydent, „GW”, nr 287 z 10.12.2002, s. 2; J. Holzer, Rozgrywki, emocje i zbrodnia. 80. Rocznica zabójstwa prezydenta Narutowicza, GW, nr 291 z 14.12.2002, s. 19-21; J. S. Majewski, 80 lat temu. Warszawa po wyborach prezydenckich 1922. Goracy grudzień powyborczy, GW (Gazeta Stołeczna), nr 292 z 16.12.2002, s. 13; J. Michałek, Strzały w Zachęcie, „Trybuna”, nr 293 z 15.12.2007, s. 8; W. Kalicki, Trzy kule dla prezydenta, GW, nr 88 z 15.04.2010, dod. „Duży Format”, nr 15, s. $13-15$.

149 J. Brzuszkiewicz, Przywołali pamięć Niewiadomskiego, GW, nr 267 z 17.11.1995, s. 2.

150 Taki charakter mają m.in. artykuły poświęcone osobie i rodzinie Eligiusza Niewiadomskiego (S. Milewski, Morderstwo manipulowane: proces Eligiusza Niewiadomskiego, „Rzeczpospolita”, nr 79 z 3.04.1999, s. 16; A. Rybak, Chory na Polskę, „Rzeczpospolita”, nr 293, (Dodatek PlusMinus), nr z 17-18.12.2011, P. 8-9.) oraz okolicznościom towarzyszącym zbrodni, czasami nawet bardzo nieprawdopodobnym (D. Baliszewiski, Zlecenie na prezydenta, „Wprost”, nr 51-52 z 25.12.2005-8.01.2006, s. 112-114. 
rzeń określiła dosadnie „mianem historii dla matołków”151. Dla Bojarskiej G. Narutowicz to symbol demokracji. Człowiek, którego zamordowano, bo przyjął wybór, dokonany przez większość - nie bacząc, co to za większośććc ${ }^{152}$. Dla autorki nie bez znaczenia był fakt, że polski gorący grudzień, który łączy ściśle ze „sprawą Niewiadomskiego”, nastąpił między puczami Mussoliniego w październiku 1922 roku we Włoszech i Hitlera w Monachium w listopadzie 1923 roku. Wydarzenia te miały według niej wiele podobieństw, gdyż każde z państw, w którym do nich doszło, odzyskało lub wywalczyło państwowość stosunkowo późno i z trudem - po dłuższym czasie rozdrobnienia; w przypadku Polski dodatkowo połączonego z niewolą. Taka sytuacja w naturalny sposób powodowała popularność haseł, które sprowadzały się do stwierdzenia, że bez buta, knuta i wzięcia narodu za mordę mowy nie ma o utrzymaniu zdobyczy, jaką było własne państwo. Polska nie stała się, jak wyraźnie podkreśliła A. Bojarska, w latach dwudziestych i trzydziestych państwem faszystowskim czy narodowo-socjalistycznym, ale było tak tylko dlatego, że nad Wisłą był J. Piłsudski. To właśnie w nim autorka upatruje osoby, która przeżyła największy wstrząs wywołany wydarzeniami grudniowymi ${ }^{153}$. „Tuż po zabójstwie Narutowicza i objęciu władzy - a jakże - przez prawicę - Piłsudski jak podkreśliła A. Bojarska - usunął się z życia politycznego. W ostatnim, kipiącym goryczą przemówieniu cytował to, co powiedział mu pierwszy prezydent Rzeczypospolitej po swym potwornym przejeździe ulicami Warszawy: Ma pan racje, to nie jest Europa. Ci ludzie lepiej się czuli pod tymi, kto karki im deptat i prat po pysku. Nie wstrząs przeżyty jakoby przez tłum był ważny, ale wstrząs, którego doznał Piłsudski. To on zaważył na dal-

151 A. Bojarska, Zastrzelony jadtospis, czyli trochę mitologii polskiej, Kraków 2004, s. 9.

152 Ibidem, s. 16.

153 W tym miejscu warto zauważyć, że w toku szkolnej edukacji historycznej, szczególnie nauczyciele mają tendencję do podkreślania przełomowego znaczenia pewnych wydarzeń. Znamienne, że dotyczy to najczęściej wydarzeń, w których bezpośrednio lub też pośrednio mieli okazję uczestniczyć. Na podstawie rozmów prowadzonych przez autora artykułu z nauczycielami historii, w ramach cyklicznie organizowanych od 2002 roku przez Sekcję Dydaktyczną Oddziału Opolskiego Polskiego Towarzystwa Historycznego, spotkań wynika, że dla najbardziej doświadczonych w pracy zawodowej, tj. minimum 20-25 lat pracy szkole takimi wydarzeniami był „karnawał Solidarności w latach 1980-1981, stan wojenny 1981-1983, wreszcie wydarzenia roku 1989 , tj. obrady okrągłego stołu i wybory czerwcowe. Nauczyciele, którzy pracę w szkole rozpoczęli w drugiej połowie lat dziewięćdziesiątych i później, wskazując na takie wydarzenia, jak śmierć Jana Pawła II w 2005 roku, czy katastrofa smoleńska z 2010 roku, a nie przystąpienie Polski do Paktu Północnoatlantyckiego w 1999 roku czy Unii Europejskiej w 2004 roku”. 
szej historii międzywojennej Polski” ${ }^{154}$. Po tym wydarzeniu Piłsudski nie był już „fanatykiem demokracji”, ani politykiem o miękkiej ręce, którego pierwotnie chciał zgładzić E. Niewiadomski.

Swoją krytyczną ocenę Polaków za polityczny gorący grudzień 1922 roku w dalszej części książki i jednocześnie w szkicu poświęconym już zupełnie innej problematyce - ocenie postaci księcia Józefa Poniatowskiego - A. Bojarska podkreśla raz jeszcze, pisząc, że: „W krótkie międzywojenne dwudziestolecie wkroczyli ludzie zdeformowani i okaleczeni niewola, ludzie mordujący swego pierwszego prezydenta, niezręczni, rozwścieczeni, pełni urazów, łamiący i psujący swą przeważająco nową własność: sejm, demokrację. Jak zagłodzeni jeńcy, którzy umierają od nagłej obfitości jedzenia, tak książę Pepi mógł być i wtedy wzorem, uczącym nieszczęsnych parweniuszy zachowania w salonie wolności. Więc tak się wtedy myśli, tak się czuje? Parweniusze nauczyliby się wszystkiego, zdążyli już dokonać wielkich rzeczy, ale zabrakło im czasu. Przyszedł wrzesień 1939 i wszystko, co po nim"155.

Konsekwencje 16 grudnia 1922 roku pojawiają się również w książkach Rafała Ziemkiewicza, w których choć porusza on głównie wątki dotyczące współczesnej sytuacji społeczno-politycznej, to jednak niejednokrotnie sięga również do historii. I tak jest też w przypadku wydanej 2008 roku pracy Czas wrzeszczacych staruszków, w której stwierdził, że z odrodzenia państwa polskiego w 1918 roku politycy odpowiedzialni za kształt Polski po 1989 roku gotowi byli wziąć tylko zabójstwo G. Narutowicza, co spowodowało, że jako pewnik przyjęli, że „[...] jakiekolwiek ożywienie narodowych i religijnych uczuć musi doprowadzić do budowy państwa wyznaniowego oraz masowego wieszania komunistów, a potem liberałów, Żydów, intelektualistów i w ogóle wszystkich, którzy by się chcieli przeciwstawić nieuchronnie ogarniającemu kraj faszyzmowi" 156 .

Przywołane wypowiedzi cenionych publicystów, zaczerpnięte z wydanych przez nich książek, nie wyczerpują prezentowanych na przestrzeni ostatnich kilkunastu lat stanowisk. Bez wątpienia są jednak reprezentatywne dla dwóch głównych nurtów postaw polskiego społeczeństwa wobec znaczenia i wpływu wydarzeń z grudnia 1922 roku na historią Polski w kolejnych dekadach XX i pierwszej XXI wieku.

154 A. Bojarska, op. cit., s. 19.

155 Ibidem, s. 69-70.

156 R. Ziemkiewicz, Czas wrzeszczących staruszków, Lublin 2008, s. 108. 
Gorący polityczny grudzień 1922 roku, choć został zażegnany, pokazał, że przed młodą polską demokracją stały nie tylko poważne wyzwania, ale wręcz walka o przetrwanie. Niespełna przed dwoma dekadami Daria Nałęcz w pracy poświęconej postawie polskiej inteligencji wobec niepodległości napisała, że reguły demokracji „[...] zakwestionowane zostały przy pierwszym starciu, a układ sił w sejmowych zapowiadał kolejne, wcale nie łagodniejsze spięcia" ${ }^{157}$. Zbliżoną opinię w tym samym czasie wyraził również powszechnie ceniony historyk Janusz Pajewski, który stwierdził, że wydawało się tylko, że wraz otwarciem pierwszego Sejmu Ordynaryjnego (28 listopada 1922 roku) i wyborem pierwszego prezydenta Rzeczypospolitej (9 grudnia 1922 roku), otworzył się nowy okres w życiu odbudowującego się państwa, okres „[...] normalnego, prawidłowego życia”. Niestety okres ten już na wstępie przeszedł wstrząs i został „zatruty” sprawą wyboru prezydenta ${ }^{158}$. Tym samym wydarzenia z grudnia 1922 roku poważnie zaciążyły na historii Drugiej Rzeczypospolitej.

W artykule wykazano, że wydarzenia gorącego politycznego grudnia 1922 roku zostały przedstawione w większości szkolnych podręczników historii, wydanych po przełomie 1989 roku, w sposób rzeczowy i zgodny z ustaleniami polskiej historiografii. Naturalnie można wskazać elementy, których dowartościowanie jest wskazane dla lepszego zrozumienia tematu przez uczniów. Czyniąc to, należy jednak pamiętać o ograniczonej liczbie godzin lekcyjnych, jakimi dysponują nauczyciele na wszystkich poziomach szkolnej edukacji historycznej. Warto przypomnieć w tym miejscu, że od 2009 roku historia obejmująca okres po 1918 roku nauczana jest już tylko w szkołach ponadgimnazjalnych. Bez względu jednak na to, w jakim wymiarze godzinowym oraz na jakim etapie nauczania historii poruszana jest kwestia wydarzeń społeczno-politycznych z grudnia 1922 roku, nie ulega wątpliwości, że na długo pozostaną one symbolem dramatu odradzającego się państwa polskiego. Emocje ujawnione w Sejmie, manifestacje i starcia na ulicach, wreszcie mord polityczny, którego ofiarą padł pierwszy obywatel Rzeczypospolitej, stanowią przestrogę. Swoistą lekcję, której nie można odrobić jednorazowo, a tym bardziej potraktować jak wielu informacji przekazywanych w szkole, czyli „zakuć, zdać i zapomnieć”. To, co wydarzyło się w grudniu 1922 roku, wbrew powtarzanym czasami opiniom, nie może

157 D. Nałęcz, Sen o władzy. Inteligencja wobec niepodległości, Warszawa 1994, s. 195.

158 J. Pajewski, op. cit., s. 199-200. 
być ocenione w kategoriach wydarzenia, z którego Polacy choć poobijani wyszli obronną ręką, a państwo w ostatecznym rozrachunku „zdało egzamin”. W grudniu 1922 roku egzaminu nie zdał nikt. Porażka była udziałem wszystkich partii i polityków oraz wspierających lub też tylko przyglądających się im ludzi. Porażki są najlepszymi nauczycielami, a kulminacja grudniowych napięć 1922 roku była taką właśnie porażką. Jeżeli będziemy o niej pamiętać, wyciągać wnioski i jednocześnie mieć stale świadomość, że skoro raz już je ponieśliśmy, to nie znaczy, że jesteśmy uodpornieni, mamy szansę na rzeczową dyskusję o przeszłości oraz lepszą przyszłość. Gwarancji nie ma, ale warto spróbować.

\section{Political hot in December of 1922 in modern historical education. The case of school textbooks for the teaching of history (Summary)}

The murder of the first President of the Second Republic of Poland Gabriel Narutowicz on $16^{\text {th }}$ December 1922 by Eligiusz Niewiadomski was one of the most dramatic events of the interwar period of Polish history. The event of this magnitude naturally took an important place in historical education. This statement refers both to the historical narrative presented in Polish school before 1939, in Poland ruled by the communist camp, i.e. between 1945 and 1989, and in free Poland after the Autumn of Nations in 1989. This article presents a synthetic analysis of the events of December 1922 in the historical school education. This means that primary sources of materials used in developing all kinds of publications have been prepared for teaching and learning history in Polish schools. In this group school history textbooks occupy a unique position. The analysis of textbooks shows that the turbulent events of December 1922 over the past ninety years has been presented not only as a part of wider historical knowledge. During his reign Marshal Pilsudski and his camp first used Narutowicz's death stressing that he was the victim of persecution of the National Democracy. Similarly, the situation was presented in terms of narrative textbooks from 1945 to 1989. During communist rule, the events of December 1922 were also used to criticize the generally political situation of the Second Republic of Poland. More balanced assessment of the situation, which does not justify the crime committed on the president, appeared after 1989. The analysis of the events of December 1922 used in historical education, cannot clearly state how much breakthrough character 
they had. This conclusion also applies to assess the proverbial pass of the exam by the Polish state and its society in the time of undeniable crisis that took place in December 1922. It also be emphasized that the facts presented to students about the title event for the last ninety years, in very different periods of Polish history were constantly reinforced by the media message. Depending on the sympathies and intentions of its authors the media message strengthens or refutes the image formed in the course of historical school education.

\section{Marek Białokur Instytut Historii, Uniwersytet Opolski e-mail:bialy@lo3.opole.pl}

